\title{
EXTENSION OF THE AT-RISK CONCEPT TO THE INVESTMENT TAX CREDIT: A SHOTGUN APPROACH TO THE TAX SHELTER PROBLEM
}

\author{
Allaire Urban Karzon* and Charles H. Coffin**
}

The Economic Recovery Tax Act of 1981 (ERTA) ${ }^{l}$ and the Tax Equity and Fiscal Responsibility Act of 1982 (TEFRA) ${ }^{2}$ constitute a bold legislative experiment: a selective restructuring of the federal taxation system as medication for a faint economy. First, the ERTA offers individuals and small businesses significant tax rate reductions to encourage increased productivity and savings. ${ }^{3}$ Second, both acts offer businesses and investors a substantially more lucrative depreciation system-the Accelerated Cost Recovery System (ACRS) ${ }^{4}$ - to stimulate capital formation. Third, the TEFRA increases Treasury revenues by restricting certain tax preferences, improving tax collection and enforcement, and increasing various excise taxes. ${ }^{5}$ Finally, and the main concern of this article, the acts revise the existing investment tax credit

* Associate Professor of Law, Vanderbilt University School of Law, B.A., 1945, Wellesley College; J.D. 1947, Yale University.

** Member of the Texas Bar, J.D., 1982, Vanderbilt University.

1. Pub. L. No. 97-34, 95 Stat. 172 (codified in scattered sections of I.R.C.). The ERTA effects the largest federal tax reduction in United States history. Congressional conferees estimated that the new tax reductions would decrease cumulative Treasury revenues by approximately $\$ 750$ billion over the next six fiscal years. H.R. ReP. No. 215, 97th Cong., 1st Sess. 289. reprinted in 1981 U.S. CODE CONG. \& AD. NEws 105, 377; see also S. REP. No. 144, 97th Cong., 1st Sess. 172, reprinted in 1981 U.S. CODE CONG. \& AD. NEws 105, 268 (sinilar estimates by the Senate Committee on Finance and the United States Department of the Treasury) [hereinafter cited as SENATE REPORT ON ERTA].

2. Pub. L. No. 97-248, - Stat. - The enactment of the TEFRA represents congressional and administration concern over the escalating budget deficits projected for the fiscal years 1983 to 1987. Congressional conferees estimated that the new provisions would increase cumulative Treasury revenues by approximately $\$ 98.3$ billion over the next three fiscal years and approximately $\$ 214$ bilion over the next five fiscal years. See H.R. REP. No. 760, 97th Cong., 2d Sess., reprinted in 1982 U.S. Code Cong. \& AD. News No. 7 (September 1982) [hereinafter cited as CONFERENCE REPORT ON TEFRA]. According to these estinates TEFRA effects the second largest tax increase in history. (The Social Security Amendments of 1977, Pub. L. No. 95-216, 91 Stat. 1510 (codified as amended in scattered sections of 26 U.S.C., 42 U.S.C.) effected the largest increase: $\$ 117$ billion over three years.)

3. See ERTA $\S \S 101,231$.

4. TEFRA § 206; ERTA § 201.

5. See TEFRA § 205; ERTA $\$ \$ 211-214$. 
provisions to make this historically important indirect government subsidy more available and more valuable. ${ }^{6}$

Although Congress expanded certain provisions of the investment tax credit, it accompanied the expansions with elaborate restrictions on tax shelters. ${ }^{7}$ Congress did this by awkwardly coupling the new law to the existing Internal Revenue Code (Code) section 465 "at-risk" limitations, which were previously used only to disallow certain artificial losses. ${ }^{8}$ In general, under the new rules, a taxpayer's investment credit is limited to the dollar amount that he has "at-risk" in otherwise eligible property he has acquired. Prior uses of the "at-risk" rules by the Internal Revenue Service as a weapon against abuse of otherwise legitimate tax privileges make integration of the two concepts neither surprising nor unusual. Congress, after all, enacted section 465 to restrict the sheltering of currently taxable income with otherwise deductible expenses incurred through activities in which the taxpayer risked no genume economic investinent. ${ }^{\text {The }}$ The tax shelter potential of tax preferences-whether deductions or credits-does not significantly depend on the forin of the preference. Limiting investment credits to amounts refiecting the taxpayer's real economic investment, therefore, is an important goal for those protecting Treasury revenues from aggressive tax planners.

The real significance of the broad incorporation of existing "atrisk" principles, however, lies in the direction to which section 46(c)(8) currently points. ${ }^{10}$ Congress' extension of section 465 "at-risk" rules in effect operates as a general statutory condemnation of nonrecourse financing, creating a presumption that such financing foreshadows either fraud or an abusive sheltering device. Yet this statutory presumption does not affect publicly held corporations. Consequently, the new rules' impact on individuals and competitive closely held businesses will create significant disparities. Because the investment tax credit was designed to encourage taxpayers to nrake certain investment decisions, and because nonrecourse financing has nrany legitinate purposes, limiting the investment tax credit through a general condemnation of nonrecourse financing creates anomalies suggesting that Congress should further revise the "at-risk" rules of the Code.

6. See TEFRA tits. II-III.

7. See TEFRA § 211 (f) (codified at I.R.C. \&46(c) (West Supp. 1982)).

8. I.R.C. $\& 465$ (1976 \& Supp. IV 1980). See generally infra notes $121-23$ and accompanying text.

9. See generally infra notes 109-23 and accompanying text.

10. I.R.C. $\S 46$ (c)(8) (West Supp. 1982). 


\section{The Investment Tax Credit}

\section{A. The Purpose of the Investment Tax Credit.}

Congress originally structured the federal income tax systein to provide the revenue needed for essential operations of the federal government. ${ }^{11}$ By including criteria for the measurement of taxpayers' net gain, Congress required individuals and corporations to bear national fiscal expenses in proportion to their ability to pay. Modernization of the income tax system, however, introduced special provisions-tax expenditures-that neither fix a scale of paynent nor contribute to an accepted definition of net income. ${ }^{12}$ Instead, the federal government

11. Congress first enacted a personal income tax as a temporary revenue measure during the Civil War. Act of Aug. 5, 1861, ch. 45, $\$ 49,12$ Stat. 292, 309, repealed by Act of July 1, 1862, ch. $119, \S 89,12$ Stat. 432, 473. The United States Supreme Court held a second general income tax law unconstitutional because it failed to apportion taxes. Pollock v. Farmers' Loan \& Trust Co.. 157 U.S. 429 (1895). The mounting financial needs of the federal government eventually resulted in the Corporation Excise Tax of 1909, ch. 6, \& 38, 36 Stat. 11, 112-17 (repealed 1913). In 1912, Congressional desire to remove sugar from the list of items subject to tariff duties, see H.R. 21, 213, 62d Cong., 2d Sess., threatened federal revenues and prompted an investigation of alternative revenue possibilities. The House Committee on Ways and Means favored extending "the operation of the corporation-tax law of 1909 to individuals, firms, and copartnerships," H.R. REP. No. $416,62 d$ Cong., $2 d$ Sess. 1 (1912), but this practical equivalent of an income tax failed to win the support of those who disputed Congress' authority to enact an income tax. Ratification of the 16 th Amendment in 1913 dissolved these concerns and enabled President Wilson and Ways and Means Committee Chairman Underwood to make their tariff reductions more attractive by counterbalancing the anticipated revenue losses with a tax levy on American mcomes. See 50 CoNG. REC. 332 (1913) (statement of Chairman Underwood). For historical summaries of the events preceding the enactment of the Income Tax Law of 1913, ch. 16, $\S 2,38$ Stat. 114, 166-81, repealed by. Act of Sept. 8, 1916, ch. 463, § 24, 39 Stat. 776, see 6 R. BAKER \& W. DodD, Public PAPERs of Woodrow Wilson, ch. 3, at 1-6 (1926); M. Chirelstein, L. Day \& E. Owens, Taxation in the United States 11 (1963); J. Duarte, The Income Tax Is Obsolete, 17-24 (1974); C. McCarthy, B. Mann, B. Abbin, W. Gregory, \& J. Lindgren, The Federal Income Tax, ITS SOURCes AND APPliCations 3-5 (1968); S. RATner, TAXation AND Democracy IN AMERICA (1967). See also Helvering v. Stockholms Enskilda Bank, 293 U.S. 84, 89 (1934) ("The general object of this act is to put money into the federal treasury . . . .").

12. In 1967 Harvard Professor Stanley S. Surrey, then Assistant Secretary of the Treasury for Tax Policy, developed the concept of tax expenditures: "Through dehberate departures from accepted concepts of net income and through various special exemptions, deductions and credits, our tax system does operate to affect the private economy in ways that are usually accoinplished by expenditures-in cffect to produce an expenditure system described in tax language." S. Surrey, The United States Tax System-the Need for a Full Accounting, Remarks before the Money Marketeers (Nov. 15, 1967), reprinted in 125-2 J. AcCT. 57, 58 (1968) [hereinafter cited as Surrey, Remarks]. Professor Surrey saw the income tax systein as comprised of two major elements:

[O]ne part comprises the structural provisions necessary to implement the income tax on imdividual and corporate net income; the second part comprises a system of tax expenditures under which Government financial assistance programs are carried out through special tax provisions rather than direct Government expenditures. This second systen is grafted on to the structure of the imcome tax proper; it has no basic relation to that structure and is not necessary to its operation.

S. Surrey, Pathways to Tax Reform: The Concept of Tax Expenditures 6 (1973). [hereimafter cited as S. SurReY, PathWaYs]. 
often uses these special provisions to achieve various economic or social objectives unrelated to pure revenue raising, providing vast subsidies without making direct government expenditures. ${ }^{13}$ The investment tax credit is one of the most significant tax expenditures. ${ }^{14}$

In 1961, when the Ainerican economy was performing significantly below its potential, President Kennedy proposed an imvestment tax credit as a centerpiece of his economic recovery program. ${ }^{15}$ Treasury Secretary Dillon argued that the tax credit constituted the most

13. In 1969 the Department of the Treasury reacted to public desires for tax reform by publishing a new method of reporting the effects of special income tax provisions. The new "tax expenditure budget" listed subsidies provided through the income tax system in a format similar to that used to list appropriated direct expenditures. See 1969 Economic Report of the President: Hearings Before the Joint Economic Comm., 91 st Cong., 1st Sess. 8 (statement of Joseph IV. Barr, Secretary of the Treasury); Hearings on Economic Analysis and Efficiency in Government before the Subcomm. on Economy in Government of the Joint Economic Comm., 91st Cong., 1st Sess. 82 (1969) (statement of Stanley S. Surrey). Congress eventually adopted the concept: it required the examination of tax expenditures as part of Congressional budgetary policy, see Congressional Budget and Impoundment Control Act of 1974, Pub. L. No. 93-344, $\S \S 3(\mathrm{a})(3), 101$ (c), 102(a), 88 Stat. 297, 299, 300, 300-01 (codified at 31 U.S.C. \$ 1302(a)(2)(3) (1976)), and required the President to include tax expenditures as an item in his recommended budget, see id. $\$ 601,88$ Stat. 297, 323-24 (codified at 31 U.S.C. $\$ 11(\mathrm{e})(1976)$ ).

Naturally, classification problems abound, and the difference between strict income tax provisions and tax expenditures is often clouded. Tax expenditure analysis draws heavily on the HaigSimons definition of net imcome. See S. SuRReY, PATHwaYs, supra note 12, at 12 . According to the Haig-Simons model, personal income is "the algcbraic sum of (1) the market value of rights exercised im consumption and (2) the change in the value of the store of property rights between the beginning and end of the period in question." H. Simons, Personal Income Taxation 50 (1938).

Some commentators question tax expenditures because such expenditures do not always seem a wise method of distributing federal largesse. They are hidden within the income tax system, bypassing the congressional decisionmaking process normally necessary for enactment and administration of direct federal subsidies. For examplc, tax-writing committees, rather than committees more knowledgeable about the substantive subject mattcr under consideration for government assistance, enact special tax provisions that arc usually subject to neither periodic review nor coordination with prior assistance prograuns. See S. SuRrey, PaTHWAYs, supra note 12, at 1-4; Surrey, Tax Incentives as a Device for Implementing Government Policy: A Comparison with Direct Government Expenditures, 83 HARV. L. REV. 705, 721, 727-31 (1970) (also noting that tax expenditures have decidedly adverse effects with respect to both horizontal and vertical equity).

14. Prior to the ERTA, the investment tax credit represented the second largest tax expenditure in the 1980 budget (measured by revenue loss), exceeded in cost only by capital gains. See $A$ Review of Selected Tax Expenditures: Hearings Before the Subcomm. on Oversight of the House Comm. on Ways and Means, 96th Cong., Ist Sess. 480 (1979) (statement of Harry S. Havens, Director, Program Analysis Division, U.S. General Accounting Office) [hereinafter cited as Hearings on Investment Tax Credit].

15. The Federal Tax System-Message from the President, H.R. Doc. No. 140, 107 CoNG. Rec. 6376, 6377-78 (1961) [heremafter cited as President's Tax Message]. President Kennedy had previously noted that "inodernization and expansion of the nation's productive plant and equipment are essential to raise productivity, to accelerate economic growth and to strengthen our competitive position in world markets." President's Tax Message: Hearings Conclucted by House Comm. on Ways and Means, 87th Cong., 1st Sess. 17 (1961) [hercinafter cited as President's Tax 
powerful and efficient stimulant available for the ailing economy. ${ }^{16}$ Congress passed the proposal in 1962.17 Since then, many coinmentators have debated the investinent tax credit's effectiveness, ${ }^{18}$ but none have denied that it is a subsidy designed to induce taxpayers to imvest in certain depreciable personal property. ${ }^{19}$ The post-1962 legislative history further establishes that the investment tax credit is the equivalent of a federal grant designed to reduce net imvestınent expense and thereby stimulate business demand for capital goods. In 1964, for example, congressional repeal of a basis adjustinent feature significantly liberalized the credit and greatly increased the incentive value of

Message Hearings], reprinted in 1 House COMm. ON Ways and MEANs, 90TH CONG., 1ST Sess., LEGISLATIVE HISTORY OF THE REvenue ACT of 1962, at 137 (1967).

16. President's Tax Message Hearings, supra note 15, at 17-23 (statement of Secretary Dillon). Secretary Dillon believed the investment credit was a more potent stinulus than either allowing for accelerated depreciation of new assets or reducing the corporate income tax rates because the credit would offset only income of companies that invested in qualifying property and would provide a greater net return on new investment; tlus "for any given cost in revenue to the Treasury over a substantial period, the increase in rate of return, and hence the stinulus to investment, would be much greater under the credit approach." Id. at 21 .

17. Revenue Act of 1962, Pub. L. No. 87-834, § 2, 76 Stat. 960,962 (codified in scattered sections of the I.R.C.). President Kennedy's original proposal used the taxpayer's current year depreciation allowance as a yardstick to coinpute the allowable tax credit. For exainple, the taxpayer could have taken a tax credit equal to $15 \%$ of the total plant and equipment cost that exceeded the current year's depreciation allowance, $6 \%$ of the investment cost that totaled between $50 \%$ and $100 \%$ of the current year's depreciation allowance, or only a small minimuin credit if the investment cost totaled less than 50\% of the allowance. See President's Tax Message, supra note 15, at 4; President's Tax Message Hearings, supra note 15, at 44-46. The articulated purpose of this margimal investment subsidy scheme was to induce extraordinary investments rather than nornal replacements. See id. at 22-23. But of. White, Illusions in the Marginal Investment Subsidy, 15 NAT'L TAX J, 26, 27 (1962) (because of recapture of depreciation, a 15\% subsidy of investinent in excess of depreciation equals pure subsidy of only $3 \%$ of purcliase price plus an interest-free loan equal to $12 \%$ of the purchase price). Almost unanimous objection by business representatives influenced the House Ways and Means Committee to reject the proposal based on depreciation allowances and adopt an overall rate of $8 \%$ instead. See generally President's Tax Message Hearings, supra note 15; Investment Credit Plan Rapped, J. Сoм. 3 (May 17, 1961).

18. See, e.g., Brown, Comments on Tax Credits as Investment Incentives, 15 NAT'L TAX J. 198 (1962); Chase, Tax Credits for Investment Spending, 15 NaT'L TAX J. 32 (1962); Coen, Tax Policy and Investment Behavior: Comment, 59 AM. ECON. Rev. 370 (1969); Coen, Effects of Tax Policy on Investment in Manufacturing, 58 AM. ECon. Rev. 200 (1968); Cook, The Investment Credit: Investment Incentive and Countercyclical Tool, 45 TAXEs 227 (1967); Jolmson \& Carey, The Effect of the Investment Credit on Equipment Replacement Decisions, 23 NAT'L TAX J. 307 (1970); White, supra note 17; Wiseman, Public Policy and the Investment Tax Credit, 16 NAT'L TAX J. 36 (1963); Woodward \& Panichi, Investment Influences of the Tax Credit Program, 18 NAT'L TAX J. 272 (1965).

19. As President Kennedy stated, "Our objective is to provide the largest possible inducement to new investment which would not otherwise be undertaken." President's Tax Message, supra note 15, at 6378. Secretary Dillon agreed: "The intent is to stimulate investment, not to give general relief to one particular group of taxpayers." President's Tax Message Hearings, supra note 15 , at 20 . 
the subsidy. ${ }^{20}$ As the American econoiny grew healthier, inflationary pressures influenced Congress to restrict demand, first by suspending the credit during 1966 and 1967, ${ }^{21}$ and then by repealing it completely in 1969.22 Two years later, however, Congress responded to a lagging economy by re-enacting a more liberal version of the investment credit. $^{23}$ In 1981 and 1982, after a decade of modification, continued

20. The investment tax credit provisions as enacted in 1962 required reduction of the depreciable tax base of any quahified property in an amount equal to the credit. See Revenue Act of 1962, Pub. L. No. 87-834, § 2(b), 76 Stat. 960, 970 (repealed 1964). Adoption of this requirement-popularly known as the Long Amendment because of its sponsor, Senator Russell Longreflected concern over the revenue cost of the new subsidy. See S. REP. No. 1881, 87th Cong., 2d Sess., reprinted in 1962 U.S. CODE CONG. \& AD. NEws 3304, 3321-22.

Although the Long Amendment may have reduced the amount of revenues lost through the investment crcdit, the basis adjustment feature also dimimished the credit's incentive effect. For example, the taxpayer could receive a tax credit in the year of a purchase, but lower depreciation bases would necessarily create relatively higher amounts of taxable income in subsequent years. Consequently, in 1964 Congress repealed this requirement returning to the subsidy concept as originally adopted by the House of Representatives. Revenue Act of 1964, Pub. L. No. 88-272, $\S 203,78$ Stat. 19, 33; see H.R. REP. No. 749, 88th Cong., 2d Sess. 34 (1964), reprinted in 1964 U.S. CODE CONG. \& AD. NEws 1313, 1343. Thereafter, the investment tax credit operated not as an additional acceleration of depreciation but entirely as a federal subsidy equal to a portion of the property's cost. Eventually, however, the inore lucrative tax benefits of the revised ACRS influenced Congress to remtroduce the concept of partial basis in the TEFRA. See infra notes $46 \& 56$. For an in-depth analysis of the effect of the basis adjustment feature, see Sunley, Towards a More Neutral Investment Tax Credit, 26 NAT'L TAX J. 209 (1973).

21. Act of Nov. 8, 1966, Pub. L. No. 89-800, 80 Stat. 1508. By October, 1966, the American economy was in its "67th month of unimterrupted expansion following the recession low reached in February 1961." S. REP. No. 1724, 89th Cong., 2d Sess. 6, reprinted in 1966 U.S. CODE CONG. \& AD. NEws 4327, 4332. Demand for machinery and equipment outstripped the country's capacity to produce these capital goods. As economic activity accelerated, inflationary pressures prompted federal monetary restraint and finally forced Congress to take action designed to restrain the excessive demand. Id. at 4332-40. Accordingly, Congress suspended the investment tax credit for property purchased between October 10, 1966, and March 9, 1967. See Act of June 13, 1967, Pub. L. No. 90-26, $§ 1,81$ Stat. 57, 57 (repealing suspension of credit for property purchased after March 9, 1967); S. REP. No. 79, 90 th Cong., 1st Sess. 1, reprinted in 1967 U.S. CODE CONG. \& AD. News 1198, 1198 (citing abatement of previously existing imflationary pressures). Under these circumstances, suspension of the investment tax credit indicates the reliance placed by both the Johnson administration and Congress on the credit as a subsidy with signiflcant potential effect on private imvestment expenditures.

22. Tax Reform Act of 1969, Pub. L. No. 91-172, § 703, 83 Stat. 487, 660-67. Additional inflationary pressures convinced Congress to abolish the crcdit for investment in property acquired after April 18, 1969. See S. REP. No. 552, 91st Cong., 1st Sess. 224-27, reprinted in 1969 U.S. CODE CONG. \& AD. NEwS 2027, 2259-62. For descriptive analyses of the credit's phase-out, see Auerbach, Investment Credit and Depreciation Before and After 1969 Reforms, 4 IND. LEGAL F. 156 (1970); Holtz \& Jenkins, The Investment Credit: Act Five-Repeal, 48 TAxes 144 (1970); Loring, How to Phase Out the Investment Credit, 29 INST. ON FED. TAX'N 687 (1971).

23. See Revenue Act of 1971 , Pub. L. No. 92-178, $\$ 101,85$ Stat. 497, 498-99 (codifled at I.R.C. $\$ \S 49-50$ (1976)). President Nixon had proposed a job development credit providing a tax credit generally cqual to $10 \%$ of the cost of new machinery and equipment produced in the United States and placed into service on or after August 16, 1971. See Hearings Before House Comm. on Ways and Means on Tax Proposals contained in the President's New Economic Policy, 92d Cong., 1st Sess. 7, 11-13 (Septeinber 8, 1971) (statement of John Connully, Secretary of the Treasury). 
liberalization, and congressional scrutiny, ${ }^{24}$ Congress again reacted to the nation's economic problems by altering the potential benefits of the investment subsidy. ${ }^{25}$

\section{B. The ERTA's Liberalization of the Credit.}

Prior to the enactment of the ERTA, the Senate Committee on Fimance candidly noted that revision of the investment tax credit was necessary because the existing rules failed to "provide the investment stimulus that is essential for economic expansion."26 The Committee recommended both a restructuring of the credit and a new cost recovery system that "provides for the more rapid acceleration of cost recovery deductions and maintains or increases the investment tax credit."27 Congress adopted the recommendation by enacting, througl the ERTA, four liberalizations in the existing investment tax credit provisions. First, the ERTA mcluded two previously excluded categories of capital assets in the definition of "eligible property." Second, the ERTA altered the formula with which a taxpayer coinputes his quali-

After August 15, 1972, the credit would have been reduced to 5\%. The enacted version of the proposal, however, generally provided a 7\% credit for eligible property either ordered after March 31, 1971 or acquired after August 15, 1971. See Revenue Act of 1971, \$ 101. The Act also codified the Asset Depreciation Range system that had been adopted under regulatory authority on June 23, 1971. See id. $\S 109$. For a thoughtful critique of the Congressional policy underlying reenactment of the credit, see Brannon, The Revenue Act of 1971-Do Tax Incentives Have New Life?, 14 B.C. IND. \& CoMm. L. REv. 891 (1973).

24. See, e.g. , Tax Reduction Act of 1975, Pub. L. No. 94-12, §301, 89 Stat. 26, 36 (codified at I.R.C. $\$ \S 46,48$ (1976) (increase of naximum credit to I0\% of qualified investment); Tax Reform Act of 1976, Pub. L. No. 94-455, $\$ \S 801-807,90$ Stat. 1520, 1580-1606 (codified in scattered sections of I.R.C.) (extension of credit for four years; revision of carry over provisions; amendinent of recapture rules for certain films and vessels); Revenue Act of 1978, Pub. L. No. 95-600, §§ 3I1317, 92 Stat. 2763, 2824-30 (codified at I.R.C. \$\$ 46-50) (Supp. IV 1980) (permanent extension of maximum 10\% credit; phased-in increase in amount of credit allowable up to $90 \%$ of tax liability in excess of $\$ 25,000$; increased credit for pollution control facilities; extension of credit to single purpose agricultural or horticultural structures, to cooperatives and to certain qualified rehabilitated structures).

25. See TEFRA; ERTA $\$ \$ 211-214$.

26. SENATE REPORT ON ERTA, supra note 1 , at 47.

27. Id. The legislative history indicates that Congress sought various objectives-frequently expressed in the negative-in its revision of the depreciation and investment credit provisions. The Senate Finance Committee, for example, noted that the existing high rates of inflation reduced the "real value" of depreciation deductions and thereby diminished the certainty, profitability, and attractiveuess of new investments in modern assets. Id. The House Ways and Means Committee echoed these concerns and also expressed dissatisfaction that

because of interactions with the investment tax credit, the current depreciation rules result in unimtended biases such that the effective tax rates on incoune from different types of equipment can differ by a factor of 10 . These biases unisdirect spending to less efficient but tax-favored investments and away from more productive investments.

H. R. REP. No. 201, 97th Cong., 1st Sess. 73 (1981). Congress also objected to the complexity of rules that taxpayers, especially small businesses, found “difficult to inaster and expensive to apply." Senate RePORT ON ERTA, supra note 1, at 47. 
fied investment in ehgible property, in effect increasing the available dollar amount of the credit. Third, the ERTA expanded the class of the credit's beneficiaries by creating a de facto "refundable" credit, through leasing provisions for those who incur little or no tax liability. ${ }^{28}$ Fourth, the new rules relaxed the required recapture of the credit in subsequent years.

1. Expanded Categories of Eligible Property. Section 48 of the Code defines the categories of property eligible for the investment tax credit. ${ }^{29}$ Prior to 1981 , ehigible property-"section 38 property"-generally included certain depreciable, tangible property with a useful life of at least three years froin the date a taxpayer placed the property in service in a trade, business or investment. ${ }^{30}$ Section 38 property included almost all types of tangible personal property, ${ }^{31}$ but the Code excluded land, buildings, and their structural components from this class of eligible properties. ${ }^{32} \mathrm{~A}$ host of borderline categories of eligible property soon developed because the Code lacked a precise, manageable definition of section 38 property. ${ }^{33}$ Further complicated by IRS

28. The TEFRA schedules the expiration of this benefit on December 31, 1983. See TEFRA $\$ 209$. For a discussion of the repeal of the safe harbor leasing provisions of section 168 , see infra notes $90-91$ and accompanying text.

29. See I.R.C. § 48(a) (1976 \& West Supp. 1982).

30. See id. $\S 48(a)(1)$.

31. I.R.C. $\$ 48(a)(1)(A)$ (1976) imcludes within the definition of eligible section 38 property all "tangible personal property" other than an air conditioning or heating unit.

32. See I.R.C. \& 48(a)(1)(B) (West Supp. 1982). Under the regulations, "tangible personal property" is defined as "any tangible property except land and improvements thereto." Treas. Reg. \& 1.48-1(c) (1965).

33. For example, the Code provides that "other tangible property" that qualifies for the credit, even if not "personal" property, must not be a building or a structural component of a building, and must fit into one of the categories set forth in I.R.C. section 48(a)(1)(B) (used "as an integral part" of certain specified activities; or classified as a research facility or facility for bulk storage of fungible commodities used "m connection with" one of the specified activities). Prior to the ERTA, section 48(a)(1) also histed four other classes of property eligible for the credit: certain elevators or escalators, simgle purpose agricultural or horticultural struetures, qualified rehabilitated buildings and quahified timber property. See I.R.C. $\$ 48(a)(1)(C)-(F)$ (1976 \& Supp. IV 1980). Obviously, in establishing these heterogeneous categories, Congress frequently blurrcd traditional distinctions between personal and real property.

Although an item appears to qualify as section 38 property, it can lose that status by falling within any of several statutory exceptions. Section 48 generally denies any investment tax credit for property used predommantly outside the United States, see I.R.C. § 48(a)(2)(A) (West Supp. 1982); but that section then excepts aireraft, ships, railroad rolling stock, comınunications satellites and telephone cables used in international communications from this denial of the credit. See id. $\S 48(a)(2)(B)$. Congress also denied the credit for property "coinpleted outside the United States" (defined to include Puerto Rico and all United States possessions) or property having a basis less than $50 \%$ of which "is attributable to value added within the United States." I.R.C. § 48(a)(7). If the President determimes, however, that the section 48 denial of credit to any article of predominantly foreign origin is not in the public interest, he may make it eligible for the crcdit by executive order. I.R.C. § 48(a)(7)(C)-(D); see also Treas. Reg. § 1.48-1(g) (1965); § 1.48-1(o) (1972). 


\section{regulations and Revenue Rulings from the Treasury, ${ }^{34}$ these tortuous descriptions of eligible property produced confusion and dispute be-}

For reasons that are not clear, Congress also denied an investment credit for section 38 property used predominantly for lodging. See I.R.C. \& 48(a)(3) (1976). Prior to the ERTA, three statutory exceptions to the lodging exclusion existed. First, furnishings qualified for the credit if used "where the predominant portion of the accommodations is used by transients": for example, in a hotel or motel. See I.R.C. \& 48(a)(3)(B) (1976). Second, the credit applied to section 38 property used in publicly accessible commercial facilities located within an otherwise ineligible lodging. For example, credit would be available for equipment in a drugstore or restaurant located within an apartment building. See I.R.C. $\$ 48(a)(3)(A)(1976)$. Third, the credit applied to "coin-operated vending machines and coin-operated washing machines and dryers" even if located in a lodging. See I.R.C. § 48(a)(3)(C) (1976); Treas. Reg. § 1.48-1(h)(2)(i) (1972). Presumably, noncoin-operated washers and dryers in the saine lodging did not deserve the tax subsidy.

Congress also disallowed the credit for other classes of property. For example, there is no credit for property used by a tax exempt organization unless it is used predoininantly in a taxable unrelated trade or business, see I.R.C. \$ 48(a)(4) (1976); no credit for property used by the United States, other governmental units, or tax exeinpt imternational organizations other than the International Telecommunications Satellite Consortium and its successors, see I.R.C. § 48(a)(5) (1976); Treas. Reg. $\$ 1.48-\mathrm{I}(\mathrm{k})$; no credit for horses (although credit is available for other livestock, see I.R.C. § 48(a)(6), (p)(6) (1976 \& Supp. IV 1980)); and no credit available for boilers fueled by oil, gas or certain petroleum products unless the boilers meet an "exeinpt use" test, see I.R.C. $\S 48(a)(10)$ (Supp. IV 1979). For a general discussion of the difficulties encountered in deterinining what property is eligible for the credit, see Note, The Great Section 38 Property Muddle, 28 VAND. L. REv. I025 (1975).

34. Because the term "tangible personal property" generally excludes buildings and other inherently permanent structures, as well as their structural components, no credit is available for swimming pools, paved parking areas, wharves, bridges, or fences. See Treas. Reg. § 1.48-I(c). Property attached to a building, however, is not necessarily an inherently permanent structure or a structural component, and may qualify for the credit. Regulations allow the credit for grocery counters, testing equipment, display racks, and neon signs located in "or attached to" a building. See id. If the item is "in the nature of machinery," rather than a structural component of a building, it can qualify for the credit even if located outside a structure. Thus, the credit applies to "a gasoline puinp, hydraulic car lift, or automatic vending machine, althougl annexed to the ground." See id. Moreover, local law does not control the issue of whether a particular itein is "tangible" or "personal" property for the purposes of the investment credit. Id.

The regulations modified the customary definition of the terin "building and structural components" by taking the position that a structure inay be so closely related to the use of the property it houses that, chameleon-like, it takes on the legal coloration and nature of that property. Indications of this relation include situations in which the structure would be replaced were the property it houses replaced; where the structure is "specifically-designed to provide for the stress and other demands" of the housed machinery; or where the structure "could not be econoinically used for other purposes." See Treas. Reg. § 1.48-I(e)(1). Structures characterized as machinery, and thus eligible for the credit, include oil and gas storage tanks, grain storage bins, silos, fractionating towers, blast furnaces, basic oxygen furnaces, coke ovens, brick kilns, and coal tipples. See id.

The Treasury has, however, found it difficult to draw the line between "inherently permanent" structural coinponents (ineligible for credit) and attached but less permanent "personal" property (eligible for credit). The Treasury lias disallowed the credit for a bank's drive-up teller's · booth (structure) but allowed credit for bank vault doors and drive-up teller's window (not structural components). See Rev. Rul. 79, 1965-I C.B. 26. In contrast, the Tax Court found a prefabricated customer booth for a film processing company not "inherently permanent" and thus qualified for the credit, see Film N' Photos, Inc. v. Commissioner, 37 T.C.M. (CCH) 709 (1978). The IRS had previously determined that a launderette contained in a house trailer mounted on concrete blocks was an inherently permanent structure not quahfying for the credit. See Rev. Rul. 291, 1977-2 C.B. 7. 


\section{tween taxpayers and the Service. ${ }^{35}$ By 1981 a maze of intricate defini- tional rules and exceptions confronted any taxpayer who sought to}

Another gratuitous complexity added by the Regulations affects air conditioning and heating units. Congress unequivocally denied the credit to such units. See I.R.C. § 48(a)(1)(A) (Supp. IV 1980). The Regulations, however, make an exception for, and do not include as a structural component, certain machinery, "the sole justification for the installation of which is the fact that such machinery is required to meet temperature or humidity requirements which are essential for the operation of other machinery or the processing of materials or foodstuffs." See Treas. Reg. § 1.481(e)(2). Machinery may meet the "sole justification" criterion even though that machinery "incidentally" provides for the comfort of personnel or serves "to an insubstantial degree" areas where temperature or humidity requirements are not essential. Treas. Reg. § 1.48-1(e)(2); $c f$. Rev. Rul. 405, 1968-2 C.B. 35 (holding that refrigeration equipment installed by a meat processor to convert a building to a cold storage warehouse qualified for credit but special insulation installed to make the building suitable as cold storage warehouse was an ineligible "structural component").

35. Cases involving outdoor advertising signs illustrate the continual wrangling between taxpayers and the IRS over whether property is "inherently permanent" and thus ineligible for the credit. See Whiteco Indus. v. Commissioner, 65 T.C. 664 (1975) (outdoor wood advertising signs, secured in place with cement, were not "mherently permanent" and qualified for credit); National Advertising Co. v. United States, $507 \mathrm{~F} .2 \mathrm{~d} 850$ (Ct. Cl. 1974) (credit granted to signs attachcd to poles and rooftops); Alabama Displays, Inc. v. United States, 507 F.2d 844 (Ct. Cl. 1974) (credit for free-standing highway billboards). But see Standard Oil Co. v. Commissioner, 77 T.C. 349 (1981) (concrete foundations designed to hold advertising sign poles and the poles embedded in thein were "inherently permanent structures" not eligible for credit).

Other examples of the confusion possible under the eligible property rcquirements include disputes over complex equipment installations: a taxpayer may obtain credit for certain components resembling machinery, even though they possess some characteristics of inherently permanent structures, but the IRS may deny credit to other components in the same system. See Weirick v. Commissioner, 62 T.C. 446 (1974) (credit granted for towers supporting ski lift because equivalent to "machmery" although permanently attached to land, but earth ramps constructed to facilitate patrons' access to ski lifts not eligible because inherently permanent structures); Priv. Let. Rul. 8,036,009, 1980 Fed. Taxes: Priv. Let. Rul. (P-H) § 44 (May 29, 1980) (snowinaking guns, flexible hoses and water punps in ski resort's snowmaker qualified for credit, but buried pipelines and electric lines essential to operate equipınent were permanent structures and did not qualify); Priv. Let. Rul. 8,009,032, 1980 Fed. Taxes: Priv. Let. Rul. (P-H) $\S 48$ (Nov. 29, 1979) (amusement slide is inherently permanent and ineligible for credit, but plastic slcds used in slide qualify).

Taxpayers acquiring sewage disposal equipment and electrical equipment have argued, with differing degrees of success, that such equipment qualifies for the credit as tangible personal property under I.R.C. \& 48(a)(1)(A) (Supp. IV 1980) because it is not inherently permanent or, in the alternative, that the taxpayer is in the business of "furnishing . . . electrical . . . or sewage disposal services" and the property is used "as an integral part" of such services and therefore qualifies for the credit under Code section 48(a)(1)(B)(ii). See Hayden Island, Inc. v. United States, 380 F. Supp. 96 (D. Or. 1974) (sewage treatment plant installed at ground level and secured to a concrete slab not inherently permanent structure and qualified for credit); Johnston v. United States, 80-1 U.S.T.C. I 9199 (D. Mont. 1979) (movable sewage system, although installed underground, qualified as tangible personal property eligible for credit even though court rejected claim of taxpayer, a trailer park operator, that he was also engaged in the separate business of furnishing water and sewage service); Graybeal v. Commissioner, 39 T.C.M. (CCH) 734 (1979) (court found that taxpayer operating recreational vehicle campground also engaged in separate business of furnishing utilities so that utilities equipment met "imtegral part" test and qualified for credit as "other tangible property"); Westroads, Inc. v. Comınissioner, 69 T.C. 682 (1978), acq. 1979-2 C.B. 2 (credit allowed for equipment relating to generation of electricity when court found taxpayer engaged in two businesses, shopping center developinent and generation of electricity, so that taxpayer met 
identify investinents eligible for the investınent tax credit. Unfortunately, the ERTA did not address tle planning problems created by this complex definition of eligible property; ${ }^{36}$ instead, Congress merely defined new categories of eligible property. ${ }^{37}$

The new categories did, however, significantly expand the scope of the tax credit. For example, the credit now extends to two previously ineligible types of tangible property: certam storage facilities for petroleum products, ${ }^{38}$ and certain railroad rolling stock. ${ }^{39}$ The ERTA also expanded the availability of the credit for mvestments in certain real property projects. Congress replaced the prior ten percent credit for qualified rehabilitation expenditures on buildings at least twenty years

the "integral part" test); Everhart v. Commissioner, 61 T.C. 328 (1973) (sewage disposal system at a shopping center inherently permanent and not qualified for credit); Priv. Let. Rul. 8,005,017, 1980 Fed. Taxes: Priv. Let. Rul. (P-H) $§ 42$ (Oct. 31, 1979) (credit denied for dam built to snpply hydroelectric power for use in cotton weaving mill when Service determined that dam not essential to operation of mill); Priv. Let. Rul. 7,725,002, 1977 Fed. Taxes: Priv. Let. Rul. (P-H) \& 265 (Mar. 22, 1977) (earthen dain constructed to supply water to a papermaking business qualified for credit because dam was an "integral part" of papermaking business).

36. Witnesses before congressional subcommittees considering revisions of the investment tax credit provisions had urged a "more rational and straightforward line of demarcation between ehigible and inehgible property," removal of "artificial distinctions" between qualified and unqualified property, and alleviation of the difficulty in distinguishing between ineligible structures and eligible equipment. HEARINGS ON INVESTMENT TAX CREDIT, supra note 14, at 232-34 (statement of Dale W. Wickhain, formerly staff counsel to the Joint Coinmittee on Taxation), at 262, 265-66 (statement of Robert T. Benz), and at 269-70 (stateinent of John P. Doane). The Service conceded that the question of what property qualifies for the credit "reinains one of the inost heavily litigated issues in the investment credit area" and attributed the problem to the failure of Congress to provide a clear legislative intent or a "consistent policy" in its criteria for distinguishing cligible from ineligible property. See also id. at 178, 192 (stateınent of Jerome Kurtz, Counmissioner, IRS).

37. This was consistent with Congress' announced intent to inaintain or increase the investment credit. SENATE REPORT ON ERTA, supra note 1, at 47.

38. Prior to the ERTA, petroleum storage facilities constituted section 38 property only if used in a manufacturing, production or extraction process. Consequently, storage facilities used only for distribution failed to qualify for the credit. See STAFF OF JOINT COMM. ON TAXATION, 97th Cong., 1st Sess., General Explanation of the Economic Recovery TaX ACt of 1981 94 (Comm. Print 1981) [hereinafter cited as JoINT CoMmitree EXPLANation of ERTA]. The ERTA eliminated this distinction by simply adding distribution storage facilities for "petroleum or any primary product of petroleuin" to section 38 property. See I.R.C. $\S 48(a)(I)(G)$ (West Supp. 1982). The term "primary product of petroleuin" applies only to the primary product of oil (not gas) as defined by Treas. Reg. $\S 1.993-3(\mathrm{~g})(3)(\mathrm{i})$. See supra JoINT CoMmitTEE ExpLANATION OF ERTA.

39. I.R.C. $\$ 48(a)(2)(B)(i i)$ (West Supp. 1982). The rolling stock extension operates through a broadening of the rules for property used outside the United States. See supra note 33 and accompanying text. Prior to the ERTA, section 48 (a)(2)(B)(ii) conferred section 38 status on rolling stock used both within and without the United States only when the equipinent was owned by a domestic railroad. Under current law, any United States person owning such roling stock-not just a railroad-1nay claiın the credit. See $\$ 48($ a)(2)(B)(ii)(I)-(II). 
old ${ }^{40}$ with three new amounts of credit: (1) a rehabilitation credit for qualified expenditures on nonresidential, depreciable buildings thirty to thirty-nine years old; 41 (2) a more generous rehabilitation credit for qualified expenditures on nonresidential, depreciable buildings at least forty years old;42 and (3) a very generous rehabilitation credit for expenditures on both nonresidential and residential depreciable certified historic structures. ${ }^{43}$

2. Increased Amount of Credit. Probably more significant than the added categories of eligible property are the potential increases in the credit useable for all eligible property. The investment tax credit is calculated, in part, as a "regular percentage" of the ainount of "quali-

40. From the enactment of the credit in 1962 until 1978, owners of buildings and their structural components could not receive the imvestment credit. The Revenue Act of 1978, however, extended the investment credit to qualified rehabilitation expenditures incurred in connection with existing buildings used in businesses or mcome producing activities and not used for residential purposes. See Revenue Act of 1978, Pub. L. No. 95-600, §315, 92 Stat. 2763, 2828 (codified at I.R.C. $\$ \$ 48(\mathrm{a})(\mathrm{l})(\mathrm{E}),(\mathrm{g})(1976$ \& Supp. IV 1980). Congress hoped to "enable business to . . . modernize existing structures" in order to promote "greater stability in the economic vitality of areas that have been deteriorating." STAFF OF JolNT COMM. ON TAXATION, 96TH CONG., IsT Sess., General Explanation of the Revenue ACt of 1978155 (Comm. Print 1979) [hcreinafter cited as JoINT COMmitTeE EXPLANATION of 1978 ACT]. Thus, section 48(a) was amended to add as eligible section 38 property that portion of the basis of a qualified rehabilitated building attributable to qualified rehabihitation expenditures. See I.R.C. § 48(a)(1)(E), (g) (1976 \& Supp. IV 1980). When considering the ERTA, Congress continued to give much weight to policy considerations not directly concerned with raising revenue or defining income. For example, Congress exainined in soine detail the possible trade-off costs of taxpayers building new structures instead of rehabilitating older buildings. JoINT COMMITTEE EXPLANATION OF ERTA, supra note 38, at 113.

41. The credit is $15 \%$ for qualified rehabilitation expenditures on a building between 30 and 40 years old. See I.R.C. \& 46(a)(2)(F)(i), (iii)(I) (West Supp. 1982).

42. The credit is $20 \%$ for qualified rehabilitation expenditures on a building at least 40 years old. See I.R.C. \& 46(a)(2)(F)(i), (iii)(II) (West Supp. 1982).

43. The credit is $25 \%$ for qualified rehabilitation expenditures on a certified historic structure. See I.R.C. $\$ 46(\mathrm{a})(2)(\mathrm{F})(\mathrm{i})$, (iii)(1II) (West Supp. 1982). Code section 48 includes anong "certified historic structures" buildings histed in the National Register of Historic Places or located in a registered historic district and certified by the Secretary of the Interior as being of historic significance to the district. See $\S 48(\mathrm{~g})(3)$. Rehabihtation undertaken on a building in a registered historic district that has not been designated as a certified historic structure qualifies for neither the general $15 \%$ nor the $20 \%$ credit unless the taxpayer obtains a certificate from the Secretary of the Interior that the building is not of historic significance to the district. See JoINT CoMmitree EXPLANATION OF ERTA, supra note 38, at 115. This reverses pre-ERTA law which allowed the general rehabilitation credit then in effect for a building in an historic district without requiring that the taxpayer affirmatively obtain a certificate from the Secretary of the Interior. See $\S 48(\mathrm{~g})(2)(\mathrm{B})(\mathrm{iv})$.

The new at-risk rnles imposed in the mvestinent credit area under Code section 46 , discussed infra text accompanying notes 124-30, do not apply to the rehabilitation tax credits because the atrisk rnles exclude from their coverage property used in a real estate activity. See I.R.C. $\S \S 46(c)(8)(A)(i i), 465(c)(3)(D)$ (West Supp. 1982). 
fied investment" made each year. ${ }^{44}$ Congress increased the amount of the imvestment credit for eligible property ${ }^{45}$ placed in service after December 31, 1980 and simplified the calculation process. Although the formula remains the saine and the regular investment credit percentage generally still' stands at $10 \%, 46$ Congress altered the rules that determine the amount of the taxpayer's "qualified investment" eligible for the $10 \%$ credit. $^{47}$

Before the ERTA, the amount of qualified investment in property depended on the property's actual useful life. For example, $100 \%$ of the basis of eligible property constituted qualified investment if that property had a useful life of at least seven years. ${ }^{48}$ If, however, the property had a useful hfe of five or six years, only two thirds of its basis

44. I.R.C. $\$ 46(a)(2)(A)$, (B) (West Supp. 1982). In addition to the regular investment credit percentage on which this article focuses, three other percentages affect the amount of the total tax credit: the "energy percentage," the "employee plan percentage," and the "rehabilitation percentage." See id. $\S 46(a)(2)(A)$. Section 46(a)(2)(C) sets forth a variable energy percentage of $10 \%$ for qualified intercity buses and biomass property; $11 \%$ for quahified hydroelectric generating property; and $15 \%$ for solar, wind, geothermal or ocean-thermal property. Section $48(1)$ describes the property eligible for the varying rates. Differing enployee plan percentages-available only to a corporation with an employee stock option plan qualified under section 49(A)-appear in section 46(a)(2)(E). Section 46(a)(2)(F) provides a rehabilitation percentage of $15 \%$ for a building at least 30 years old, $20 \%$ for a building at least 40 years old, or $25 \%$ for a certified historic structure. For an explanation of the ERTA's impact on the definition of property entitled to a tax credit for rehabilitation, see supra notes $40-43$ and accompanying text.

45. See supra text accompanying notes $29-43$.

46. The combined effect of the capital recovery provisions of the Code under the ERTA-the regular investment credit and the cost recovery deductions allowed under the ACRS-often allowed greater tax benefits in the year of investment than expensing the full cost of the property. See Staff of Joint Comm. on Taxation \& Staff of House Comm. ON Ways \& Means, 97th Cong., 2D Sess., Description of Possible Options to InCRease Revenues 101-02 (Comm. Print 1982) [hereinafter cited as Description of Options to INCREASE ReVenues]. In 1982, Congress reacted to fears of overgenerous tax benefits fiowing from the ACRS, in part, by reenacting a basis adjustment provision. See TEFRA § 205; supra note 20; infra note 56. The TEFRA also provided that a taxpayer could avoid this reduction of basis by electing a lesser regular investment credit percentage-in general, two points lower than the regular percentage. See I.R.C. $\S 48$ (a)(4) (1976 \& West Supp. 1982). The conference report indicates that this election is intended as a rehief provision:

A taxpayer who makes this election does not have to make a basis adjustment. In the case of partnerships, the election is made at the partnership level. The election is intended to deal with the case in which a taxpayer cannot clain all of the regular investment credits he earns because of the 85-percent-of-tax-liability limitation. In these cases, taxpayers could be forced to make a basis adjustment and suffer a deferral of deductions for which they would have received a tax benefit, because they earn credits they will be able to use only after carrying them forward for several years. Under the conference agreement, these taxpayers are able to avoid this problem by electing the reduced credit.

CONFERENCE REPORT ON TEFRA, supra note 2, at 481-82.

47. See ERTA \& 211 (a).

48. I.R.C. $\S 46(c)(2)$ (West Supp. 1981). The Code required the purchaser of eligible property to use the same useful life for investment credit purposes that he adopted for depreciation purposes. 
constitued qualified investinent. ${ }^{49}$ Only one third of a property's basis was qualified investment if the property liad a useful life of three or four years, ${ }^{50}$ and no portion of the basis of property with a useful life of less than three years was a qualified investinent. ${ }^{51}$

Under the ERTA, the amount of the qualified investinent for property placed in service after December 31, 1980 depends not on the property's useful life, but on the recovery class to which the asset belongs under the ACRS.52 If the eligible property falls within a recovery class of at least five-year property, ${ }^{53}$ then $100 \%$ of the basis of that property constitutes qualified investment. Sixty percent of the basis of eligible tliree-year property, the lowest ACRS class, qualifies under the new liberalized provisions of ERTA. ${ }^{54}$ The introduction of this new "two-tier" effective investment credit rate ${ }^{55}$ enhances the value of the credit as a subsidy in two ways: (1) fewer uncertainties created by the Code's artificial concepts of an asset's useful life accompany planned

49. Id.

50. $I d$.

51. See id.

52. See I.R.C. $\S 46(\mathrm{c})(7)$ (West Supp. 1982). Under the Accelerated Cost Recovery System (ACRS), see id. $\S 168$, the Code divides property into five classes instead of the more than 100 different property classes of the old Class Life Asset Depreciation Range System (ADR) guide to an asset's useful life. See Treas. Reg. $\S 1.167$ (a)-11 (1970); Rev. Proc. 77-10, 1977-1 C.B. 548. The ACRS provides a taxpayer with capital cost recovery through "accelerated methods over predetermined recovery periods that are generally unrelated to, but shorter than, prior useful lives." See JoINT COMmitTeE EXPLANATION OF ERTA, supra note 38, at 75-76. Specifically, the ACRS es. tablishes 3-year property, 5-year property, 10-year property, 15-year real property and 15-year public utility property classes. See I.R.C. $\$ 168(c)(2)$ (Wcst Supp. 1982).

53. I.R.C. $\S 46(c)(7)(A)$ (West Supp. 1982). Three-year property includes depreciable tangible personalty with a class life under the ADR system of four years or less and property used in connection with research and experimentation. Common assets in the three-year class are cars, light-duty trucks, and research and experimentation equipment. Five-year property is the catchall classification for eligible tangible property that does not fall into any of the other specified recovery classes. As a result, most eligible depreciable personal property now falls within the five-year class and generates the full $10 \%$ investment credit.

54. I.R.C. $\S 46(\mathrm{c})(7)(B)$ (West Supp. 1982). See supra note 53. Two commentators have suggested that assets with a useful life of less than three years, previously ineligible for accelerated depreciation and the investment credit, will now be included in the 3-year ACRS recovery class and will therefore qualify for accelerated recovery under section 168 . These assets include items such as glassware, silverware, linens, and special tools used in the manufacture of glass products. If this observation proves correct, $60 \%$ of the basis of these assets, which never before qualified for an investment tax credit, will now generate a credit. See Luscombe \& Chevis, Faster, Simpler Depreciation Rules A vailable for All Property Under the New Tax Legislation, 55 J. TAX'N 194, 195 n.7 (1981).

55. "Effective investment credit rate," as used in tlis article, means the regular investment credit rate multiplied by the percentage of the basis of the eligible property that represents "qualified investment." For example, eligible three-year property under the ACRS, for whicls $60 \%$ of basis may be used $\mathrm{m}$ calculating the credit, will yield a $6 \%$ effective rate: $60 \%$ basis $\times 10 \%$ regular percentage $=6 \%$ effective rate. 
business investments; and (2) acquisition of short-lived section 38 property now entitles the taxpayer to comparatively greater credit benefits. ${ }^{56}$

For example, eligible property that the taxpayer placed in service before January 1, 1981, and that had a four-year useful life under the old ADR, will generate an effective investment credit rate of $31 / 3 \%$. Identical property placed in service after December 31,1982 will fall within the three-year ACRS recovery class and thereby generate an effective rate of either $6 \%$ or, if subject to the basis adjustment feature of section $48(\mathrm{~g})$, an elective rate of $4 \%$. Eligible property in the five-year recovery class will generate either a $10 \%$ or $8 \%$ credit, as compared with the $62 / 3 \%$ credit generated prior to the ERTA.

Even if the taxpayer exercises the option under the Code of extending recovery through ACRS-using deductions over a period of time longer than the recovery class to which the property belongs ${ }^{57}$ the new ACRS recovery classification still controls the investinent tax credit and produces the more lucrative two-tier benefits. ${ }^{58}$ If section 38 property does not fall within the definition of "recovery property," however, the pre-ERTA three-tier system determines the amount of qualified investment. 59 As an illustration, the ERTA excludes from its definition of recovery property, under an "anti-churning" concept, ${ }^{60}$

56. Although the TEFRA changes some investment credit provisions, it aims more generally at reducing the benefits of the ACRS. The ERTA provisions for an increased amount of qualified investment in eligible property technically survived congressional enactment of the TEFRA in 1982. Reintroduction of a variation of the original basis adjustment feature will, however, increase the net cost of investment in property placed in service after December $31,1982$.

Under the ERTA provisions, $100 \%$ of the basis of section 38 property generally qualified for ACRS deductions. A taxpayer reduced the basis of property by only the full amount of any qualified credit available for expenditures on qualified rehabilitation of certain nonhistoric structures. See I.R.C. $\$ \S 48(\mathrm{~g})(5), 1016$ (a)(23) (1976 \& West Supp. 1982). The TEFRA, on the other hand, requires taxpayers to reduce the basis of eligible section 38 property by $50 \%$ of the amount of any regular, energy, or certified historic structure investment tax credit. TEFRA $\$ 205$ (a). (A taxpayer may avoid the basis adjustment by electing a two percentage point reduction in the credit. See supra note 46.) The new basis reduction provisions apply generally to property placed in service after December 31, 1982, but are subject to several important transitional rules that may exempt certain property, under certain conditions, from the basis adjustment-even though placed in service as late as December 31, 1985. See id. $\$ 205$ (c).

The TEFRA also includes basis adjustment provisions for disposition of previously adjusted section 38 property. Immediately before a disposition of previously adjusted section 38 property. the taxpayer must increase the basis of that property by an amount equal to $50 \%$ of any recaptured credit. See id. § 205(a). Thus, the taxpayer who receives less than a full tax credit benefit because of recapture from an early disposition of eligible property may reflect loss of that benefit by readjusting upward the basis of the disposed property. For discussion of general rules of investment credit recapture, see infra notes $92-107$ and accompanying text.

57. I.R.C. \& 168(b)(3) (West Supp. 1982).

58. See Joint Committee Explanation of ERTA, supra note 38, at 95 .

59. See supra text accompanying notes $48-51$.

60. I.R.C. $\S 168(\mathrm{e})(4)$ (West Supp. 1982). For a discussion of the anti-churning rules and the definitions of a "related person," see JoINT COMMITTEE EXPLANATION of ERTA, supra note 38. at $108-09$. 
certain property placed in service prior to January 1, 1981, and transferred to a related person after Deceinber $31,1980 .{ }^{61}$ This exclusion prevents the taxpayer froin taking advantage of the increased ACRS and investment credit benefits by artificially reclassifying the property so as to trigger the old three-tier systein. ${ }^{62}$

The changed law inost directly benefits purchasers of new eligible property, but it also increases the potential credit for acquisition of used section 38 property. ${ }^{63}$ By 1985 the ERTA will increase the maximun amount of used property that may constitute qualified investment during any one taxable year froin $\$ 100,000$ to $\$ 150,000.64$ It does not, lowever, relax the definitional distinction between new and used section 38 property. 65

Congress also enlarged the time fraine during which a taxpayer can benefit from the investment credit. In any taxable year the amount of useable investment credit lias always been subject to a ceiling based on the taxpayer's "liability for tax." 66 Since 1978 the formula used lias permitted the credit to offset total tax liability in any tax year by an anount equal to $\$ 25,000$ plus a percentage of the taxpayer's tax liabil-

61. See I.R.C. § I68 (West Supp. 1982).

62. Also excluded from the ERTA's definition of "recovery property" and, therefore, from the increased benefits of the new credit computations, is property that the taxpayer elects to depreciate under any method not expressed in a terin of years (for example, the unit of production method or the income forecast inethod, see $\S 168(\mathrm{e})(2)$ ) or certain public utility property, see $\S 168(\mathrm{e})(3)$. The favorable provisions of prior law nevertheless continue to apply to pollution control facilities, see $\S 46(c)(5)$ (qualified investment equals $100 \%$ even though five or six year useful hife), and commuter highway vehicles, see $\$ 46(c)(6)$ (qualified investment equals $100 \%$ even though three, four, five, or six year useful life).

63. See I.R.C. $\S 48(c)(2)$ (West Supp. 1982).

64. See id. The new rules limit a taxpayer's qualified investınent in used property phase in this ceiling over four years, providing an interim ceiling of $\$ 125,000$ during that time.

65. Compare I.R.C. $\S 48($ b) (1976) with I.R.C. $\S 48$ (c) (West Supp. 1982). If the taxpayer first uses the property, or if he constructs, reconstructs, or erects the property, it is classified as "new" section 38 property. See Treas. Reg. §§ 1.48-2(a), 1.48-3 (1981).

The ERTA did repeal the requirement that property eligible for the elective credit for qualified progress expenditures incurred on a long-term construction project have a useful life of at least seven years. See $\S 46(d)(I)$. Henceforth, if the property falls within one of the ACRS recovery classes, the taxpayer's quahified investment will depend on the percentage normally associated with the recovery class into which the taxpayer anticipates the property will fall when ultimately placed in service. See supra text accompanying notes 52-54. On the other hand, the qualified imvestment in non-recovery class property will depend on a "reasonable expectation" of its useful hife when ultimately placed in service. See $\S 46(\mathrm{~d})(1)($ A)(ii); H. R. REP. No. 215, 97th Cong., 1st Sess. 216-17 (1981).

66. For purposes of the annual ceiling on the credit, the term "liability for tax" means the normal tax imposed by chapter 1 of the Code reduced by the credit for foreign taxes and the credit for the elderly. See I.R.C. $\S 46$ (a)(4) (1976). The term does not include, and the investment credit cannot be used to offet, certain other special taxes, such as the minimum tax on tax preferences, the accumulated earuings tax, and the personal holding company tax. See id. 
ity in excess of $\$ 25,000.67$ The percentage of tax hability in excess of $\$ 25,000$ is $90 \%$ for tax years ending in $1982^{68}$ and $85 \%$ for tax years beginning after December 31, 1982.69 Prior to the ERTA, the amount of the investment credit not useable in any year due to the tax liablity ceiling could be carried back and applied against the taxpayer's tax hability for the preceding three years and carried forward and applied against his tax liability in the next seven years. ${ }^{70}$ The ERTA expands these carryover provisions. Excess investment credit can still be carried back to the prior three years, but for years ending after December 31, 1973, the ERTA allows unused investment credits to be carried forward to each of the fifteen years succeeding the unused credit year. ${ }^{71}$

3. An Experiment: Granting the Benefits of the Credit to Taxpayers With Little or No Tax Liability Through Equipment Leasing Provisions. Besides increasing the anount of the investment tax credit and its availability to the usual purchaser of qualified property, the ERTA temporarily expands the scope of the subsidy to benefit taxpayers who incur hittle or no tax liability. Ordinarily such taxpayers cannot take advantage of a credit against tax. A government subsidy administered through the Internal Revenue Code necessarily limits its benefits to those within the tax system, and those who incur no tax liability against which a credit can apply derive no benefits-and therefore experience no incentive-from a subsidy structured as a credit. The government bestows its largess only on those who make taxable profits; ${ }^{72}$ tax exempt organizations, government institutions, and even taxable persons who currently are not profitable fail to receive the full benefit of the government charity.

Opponents of tax expenditures tout this shortcoming as evidence of the imequity of indirect tax expenditures. ${ }^{73}$ Professor Surrey, for ex-

67. See I.R.C. § 46(a)(3) (1976 \& Supp. IV 1980). Congress has steadily liberalized the credit by increasing the ceiling percentage applied to tax liability in excess of $\$ 25,000$ from $50 \%$ for tax years ending prior to 1979 to $60 \%$ (1979), $70 \%$ (1980), $80 \%$ (1981) to the current $90 \%$.

68. I.R.C. \& 46(a)(3)(B) (1976 \& Supp. IV 1980).

69. Effective with taxable years beginning after December 31, 1982, the TEFRA reduces froin $90 \%$ to $85 \%$ the percentage of income tax liability in excess of $\$ 25,000$ that may be offset by the investinent tax credit. See TEFRA \$205(b).

70. See I.R.C. $\S 46(b)(1)$ (West Supp. 1982).

71. ERTA § 207(c)(1) (codified at I.R.C. $\S \S 46(b)(1), 50(b)$ (1) (West Supp. 1982)).

72. Although the carryover provisions were designed to help loss companies, see supra text accompanying notes $67-71$, the carryback feature has no value to a new business without prior earnings, or to an established corporation that has experienced three years of losses which have eliminated tax liability during those years. The carryforward provision, on the other hand, does have a limited value: it offers a proinise of future benefits when and if the coinpany becomes profitable. The coinpany inay, however, need more immediate econounic benefits to inake the incentive effective.

73. See Surrey, supra note 13 , at $720-25$. 
ample, points to "inequitable effects and upside-down benefits" and concludes that direct government support is generally preferable to the current system of tax incentives. ${ }^{74}$ Advocates of the investment credit, however, have made similar observations and have concluded that the real inequity of this subsidy stems from an artificial limitation based on the recipient's tax liability. ${ }^{75} \mathrm{~A}$ credit saddled with this limitation gives hittle aid to those industries that Congress intended to benefit-industries weakened by competition from foreign imports and industries with inadequate tax liability against which to offset the credit. ${ }^{76}$ Many imvestment credit analysts therefore advocate repeal of this liability ceiling and adoption of a refundable credit for taxable persons without adequate tax liability. ${ }^{77}$

Although a refundable credit would further the concept of a pure economic subsidy, Congress has considered this solution unpalatable on adininistrative and political grounds. ${ }^{78}$ The ninety-seventh Congress did, however, attempt to reinedy the inequity by indirectly providing soine economic benefit from the investment credit without regard to the recipient's tax liability. ${ }^{79}$ The reinedy consists of certain safe harbor provisions that, in effect, permit the transfer of otherwise unuseable tax credits froin one corporation to another corporation-a profitable one-that can realize an immediate tax reduction from the credit. The profitable corporation can, by acquiring certain section 38 property, channel these tax savings back to the otherwise ineligible corporation. ${ }^{80}$

74. Id. at 722 .

75. See Hearings on Investment Tax Credit, supra note 14, at 218-22 (statement of Dale W. Wickhain). Under the existing investment credit system, a large, profitable company would effectively spend only $\$ 9,000$ for $\$ 10,000$ worth of equipment after taking account of the credit. A small, family enterprise with no profits to generate tax liability would have to expend the full $\$ 10,000$ for such equipment; see also id. at 169 (statement of Emil M. Sunley, Deputy Assistant Secretary of the Treasury for Tax Policy).

76. See Sunley, supra note 20, at 216; Hearings on Investment Tax Credit, supra note 14, at 286-87 (statement of James D. McKevitt, National Federation of Independent Business), 219-22 (statement of Dale W. Wickham).

77. See Hearings on Investment Tax Credit, supra note 14, at 170-71 (statement of Emil M. Sunley, Deputy Assistant Secretary of the Treasury for Tax Policy), 218-22 (statement of Dale W. Wickham).

78. As one cominentator has noted, the Departinent of the Treasury is composed of "tax lawyers trained to think in tax concepts, . . . [b]ut tax concepts . . . often have little relevance to the development of properly structured spending programs." McDaniel, Simplification Symposium Federal Income Tax Simplification: The Political Process, 34 TAX L. Rev. 27, 33-34 (1978). See Hearings on Investment Tax Credit, supra note 14, at 197-98 (Treasury responses to questions on investment tax credit).

79. ERTA $\S 201$ (a) (codified at I.R.C. $\S 168(f)(8)$ (West Supp. 1982)).

80. See JoInt CommitTEe Explanation of ERTA, supra note 38, at 102. 
In theory, corporations could always have obtained an investment credit indirectly by leasing equipment from profitable companies that could absorb, with their tax liability, the benefits of the investment credit. Because of this tax benefit, the lessors could charge the lessees lower rent. Prior to the ERTA, however, frequent disputes over the characterization of the transaction-whether it was a lease that would generate the indirect benefit or a conditional sale or financing agreement that would not-defeated effective use of this technique to expand the value of the investment credit. ${ }^{81}$ If the IRS characterized the arrangement as a lease, the lessee could deduct rental payments for use of the property in its trade or business; the lessor would retain ownership of the property entitling it to applicable depreciation deductions and mvestment tax credits associated witl ownership, and the lessor would recognize the lessee's rental payments as ordinary income. ${ }^{82}$ On the other hand, if the Service recast the transfer as a financing arrangement or as a conditional sale, the "lessee" would obtain ownership for tax purposes. This would entitle it to depreciation deductions and investment tax credits, which it frequently could not use. Moreover, the lessee would lose its deduction for "rental" payments. ${ }^{83}$ Consequently, the overall expense of acquiring equipment was greater when the Serv-

81. See, e.g., Rev. Proc. 30, 1976-2 C.B. 647; Rev. Proc. 28, 1975-1 C.B. 752; Rev. Proc. 21. 1975-1 C.B. 715. In these Revenue Procedures, the Service required of genuine leasing arrangements that (1) the lessor have at least a $20 \%$ at-risk investment im the property; (2) the lessor derive certaim specified economic and business advantages from the transaction apart from tax benefits; (3) the lessee not have the right to purchase the property at a price below fair market value; (4) the lessee not have an investment in the lease and not lend any of the purchase price to the Iessorowner, and (5) at the end of the lease term, use of the property by someone other than the lessee be commercially feasible. See JoINT CommitTeE ExPLANATION OF ERTA, supra note 38, at 103.

82. For the general economic advantages to the seller-lessee in a transaction treated as a genuine sale-leaseback, see Cary, Corporate Financing Through the Sale and Lease-Back of Property: Business, Tax, and Policy Considerations, 62 HARV. L. REv. 1 (1948). The term "sale-leaseback" arose because the lessee often sells the equipment it uses to the lessor before leasing it back. See infra text accompanying note 89.

83. In determining whether a sale-leaseback constitutes, for tax purposes, a true lease or a financing agreement, both the Service and the courts have adopted an "objective economic realities" test. See Frank Lyon Co. v. United States, 435 U.S. 561 (1978), in which the Supreme Court reaffirmed the economic substance approach and concluded that a lease was in fact a "lease" for tax purposes. In so doing, the Court reversed the Eighth Circuit, which had upheld the Commissioner's disallowance of depreciation deductions to a buyer-lessor by viewing the transaction as a loan rather than a sale and leaseback. See Wolfman, The Supreme Court in the Lyon's Den: A Failure of Judicial Process, 66 CORNELL L. Rev. 1075 (I981). Under the same economic substance test, the Court of Appeals for the Third Circuit sustained the Commissioner's disallowance of deductions for "rental" payments from a seller-lessee to the buyer-lessor because the court found that the substance of the transaction was a loan rather than a sale-leaseback. Sun Oil Co. v. Commissioner, 562 F.2d 258 (3d Cir. 1977), cert. denied, 436 U.S. 944 (1978). 
ice refused to recognize these transactions as true leases, ${ }^{84}$ and taxpayers often could not meet strict IRS requirements for advance letter rulings on the characterization of a particular transaction..$^{85}$

The ERTA swept away the IRS guidelines, establishing in their place a guarantee that a transaction would be treated as a lease, with concomitant tax benefits, if it met five safe harbor requirements. ${ }^{86}$ Furthermore, Congress directed that the IRS consider only these five factors. 87 Unprofitable and profitable corporations can enter into a transaction called a lease solely to transfer certain tax benefits to the unprofitable company. ${ }^{88}$ The typical safe harbor lease under this provision worked as follows: 1) corporation A purchases eligible equipment, obtaining the right to depreciation deductions and investment credits, but incurs insufficient income tax hability to absorb the tax benefits; 2) corporation A "sells" the equipment, together with the associated depreciation deductions and investment credits, to $B$, a profitable and eligible corporation that can decrease its tax liability with the

84. For a recent review of the commercial advantages resulting when a transaction is characterized as a sale and leaseback, rather than as a loan, see Del Cotto, Sale and Leaseback: A Hollow Sound When Tapped?, 37 TAX L. REv. 1, 3-9 (1981).

85. See the Revenue Procedures cited supra in note 81. Prior to the ERTA, users of the saleleaseback technique faced administrative suspicion and judicial uncertainty. The Service took the position in its Examination Tax Shellers Handbook that its agents should closely examine sale and leaseback transactions because of their potential for tax avoidance. See $\mathrm{CCH}$ Internal Revenue Manual, Audit Volume 1, MT 4236-1. After the Supreme Court's decision in Lyon, the judicial "economic reality test" offered taxpayers hittle certainty in predicting whether a court would label a particular transaction a sale and leaseback or a financing device. See Del Cotto, supra note 84, at $40-45$.

86. Under the safe harbor provisions, a transaction qualifies as a lease if (1) all parties elect to treat the agreement as a lease; (2) the lessor is (a) a corporation other than a subchapter $\mathrm{S}$ corporation or a personal holding company, (b) a partnership, all of whose members are eligible corporations, or (c) a grantor trust where the grantor and the beneficiaries are all eligible corporations; (3) the lessor has a minimum at-risk imvestment of $10 \%$ of the adjusted basis of the property; (4) the lease term does not exceed a certain period; and (5) the property is "qualified leased property." See 1.R.C. $\S 168(f)(8)(A),(B)$ (West Supp. 1982); see also Joint CommitTEe Explanation of ERTA, supra note 38, at 103-04.

87. I.R.C. $\$ 168(f)(8)(C)$ (West Supp. 1982). The legislative history spells out the factors previously established by the Service that Congress intended to be ignored. Previously, the Service imquired whether (1) tax savings alone made the transaction economically viable; (2) the lessee was, under local law, the owner of the property; (3) at the end of the lease, only the lessee would find the property commercially usable; (4) the agreement provided that the property might, or must, be bought or sold at the end of the lease at a fixed or determinable price, or provided for an upward or downward rental adjustment to refiect the difference between the expected value of the property at the end of the lease and its actual sales price; and (5) the lessee or a party related to the lessee had provided direct financing, or had guaranteed financing for the transaction in an amount up to $90 \%$ of the total investment. See JoINT COMMITTEE EXPLANATION OF ERTA, supra note 38, at 104.

88. The legislative history baldly states: "Because the leasing provision was intended to be only a transferability provision, many of the transactions that would be characterized as a lease under the safe harbor will have no business purpose (other than to transfer tax benefits)." Id. 
tax benefits; 3) as part of the negotiations between A and B, and in exchange for the transfer of the property and the tax benefits, coinpany $B$ agrees to "lease" the equipment back to A and to charge A lower rental payments that reflect, and are made economically feasible by, the lower tax liability enjoyed by corporation $B$ as a result of the transferred tax benefits. Although $B$ initially reaps the tax saving from the depreciation deduction and investment credits, Congress intended the bulk of the tax saving to be channeled back to A, the unprofitable company, through reduced rental payinents for the equipinent. The safe harbor equipment lease constitutes the ninety-seventh Congress's creation of a de facto refundable credit. Unfortunately, the ninety-seventh Congress offered this ingenious relief only to businesses using the corporate form, and then only to established, widely held corporations. ${ }^{89}$

In 1982, Congress cured this disparity, but the cure was negative rather than positive. Although Congress apparently recognized the benefits of the safe harbor leasing system of transferability, the political pressures arising from public perceptions of the safe harbor rules ${ }^{90}$ led to their repeal. The TEFRA curtails the transfer of tax benefits from ACRS deductions and the investment tax credit via artificial safe harbor leases by enactimg several new restrictions and scheduling complete repeal of the provisions for leases entered into after December 31, 1983.91 The investment tax credit-an inportant indirect government subsidy-will once again benefit only those taxpayers who prosper, generate profits, and mcur sufficient tax liability to absorb the credit.

4. Decreased Recapture of the Credit. Supporters of the investment credit have long objected to the coinplexity of its recapture provisions and the length of tinne during which the exposure to recapture

89. See I.R.C. § 168(f)(8)(B)(i) (West Supp. 1982).

90. Perceptions of inequity arose from several factors: (1) safe-harbor leasing permits transactions entered into solely for tax reduction purposes; (2) safe-harbor leasing inakes possible trafficking in tax benefits; (3) safe-harbor leasing allows large profitable corporations to purchase sufficient tax benefits to ehminate current tax hability and sinultaneously use carryover benefits from prior years to obtain current refunds; (4) individuals cannot obtain safe-harbor leasing benefits; (5) safe-harbor leasing makes available a variety of tax benefits other than ACRS deductions; and (6) safe-harbor leasing puts some corporations in a better position than repeal of the corporate income tax would. Some critics have also cited safe-harbor leasing as an inefficient means of achieving the desired transfer of tax expenditure benefits to those outside the income tax structure. Obviously, unscrupulous lessors and other third parties have the opportunity to retain tax benefits without offering the lessee reduced lease payıncnts. Insofar as these intended benefits lie outside the control of tax administrators, either refundability of tax revenue or direct government subsidies would offer more efficient ineans to achieve the same stimulus. See Description of OPTIONS TO INCREASE REVENUES, supra note 46, at 112-17.

91. See TEFRA \& 209. 
persists. ${ }^{92}$ Disposition of investinent credit property before the expiration of an appropriate holding period causes credit recapture. ${ }^{93}$ The amount recaptured depends upon the length of time the taxpayer actually held the property prior to disposition. ${ }^{94}$ For example, before the ERTA if a taxpayer acquired property with an estimated useful life of at least seven years for a price of $\$ 18,000$, he qualified for the full $10 \%$ credit for seven-year property in the amount of $\$ 1,800$. If the taxpayer sold the property during year eight, he would have nothing to subject to recapture because he would have held the property for the full sevenyear period. If, however, the taxpayer disposed of the property after year three, he could keep only $\$ 600$ - the $3 \frac{113 \%}{3}$ credit appropriate for property having a three-year useful life and held for three full years. The excess $\$ 1200$ would have to be recaptured from the original credit by adding this amount back to his tax liability, without interest, in the year he disposed of the property. ${ }^{95}$

On the one hand, complexity arises because, for recapture purposes, a disposition occurs not only on sales and exchanges of the property but also in a variety of other situations, regardless of gain or loss. Gifts, trade-ins, corporate distributions in liquidation, in-kind property dividends, sales by a corporation in an otherwise tax-free liquidation under section 337, and similar transactions are all dispositions. ${ }^{96} \mathrm{Re}-$ capture also occurs if the property ceases to be section 38 property; for example, if the taxpayer converts it to personal use or to use outside of the United States. ${ }^{97}$ On the other hand, even though the taxpayer has not held the property for the full investment credit holding period, re-

92. See, e.g., Hearings on Investment Tax Credit, supra note 14, at 202, 205 (statement of Professor Gerard Brannon), 225-26 (statement of Dale W. Wickham), 180-81 (statement of Jerome Kurtz, Commissioner, Internal Revenue Service, concerning special difficulties recapture poses for Service).

93. For the recapture rules prior to the enactment of ERTA, see I.R.C. $\$ 47$ (a)(1) (1976).

94. Id.

95. See Treas. Reg. § 1.47-1(a) (1967).

96. The statute mandates recapture if the property "is disposed of, or otherwise ceases to be section 38 property with respect to the taxpayer before the close of the claimed investment credit holding period." I.R.C. \& 47(a)(1) (1976) (emphasis added). See Treas. Reg. \$ 1.47(2)(a)(1) (1967). In most corporate hquidations, the original taxpayer ceases to exist and recapture therefore occurs. See infra note 100 and accompanying text.

97. At the start of each taxable year during which the taxpayer must hold the property, the taxpayer must redetermine whether the property qualifies as section 38 property. See Trcas. Rcg. $\S 1.47-2(a)(2)(i)$ (1967). Property ceases to qualify, for example, if in a later year it is used predominantly outside of the United States, see Treas. Reg. $\$ 1.48-1(\mathrm{~g})(1)(\mathrm{i})(1964)$, or is converted from business to personal use, see Treas. Reg. $\$ 1.47-2(e)$ (1967). Although potential recapture confronts a taxpayer annually, this is a one-sided arrangement: if property was not originally ehigible for the credit when the taxpayer placed it in service, he cannot subsequently benefit by waiting for ineligible property to become eligible. Thus, if property was ineligible when placed in service because predominantly used outside the United States, it does not become eligible for 
capture does not accompany a transfer of property on the death of the individual owner, ${ }^{98}$ a corporate tax-free transfer, ${ }^{99}$ or a transaction representing a "inere change in the form of conducting busmess." 100

These various rules on what does or does not constitute a premature disposition giving rise to recapture have engendered continuing dispute between taxpayers and the Service.101 Those favoring a

credit in a later year even if permanently returned for use in the United States, see Treas. Reg. $§$ $1.48(1)$ (g)(ii) (1964).

Destruction of section 38 property by casualty after April 18, 1969, does not require a recapture of credit, although a similar event occurring before that date did cause recapture. See Treas. Reg. \& 1.47-3(c) (1971).

98. See I.R.C. \& 47(b)(1) (West Supp. 1982); Treas. Reg. § 1.47-3(b)(1) (1967). Recapture will occur if the taxpayer executes a pre-death gift despite the inclusion of the value of the gift in the gross estate.

99. Recapture does not occur when, under section 381 , section 38 assets are transferred in a tax-free hquidation or reorganization. See I.R.C. $\$ 47(b)(2)$ (West Supp. 1982). Section 381(a), however, applies to hquidations of $80 \%$ owned subsidiaries only if the basis of the assets is carried over under section 334(b)(1). For distributions occuring before September 1, 1982, if there is a tax-free liquidation of an $80 \%$ owned subsidiary under section 334(b)(2) (no carryover of basis of assets) recapture occurs. See Rev. Rul. 461, 1973-2 C.B. 10; Rev. Rul. 391, 1970-2 C.B. 3. The TEFRA, lowever, repeals section 334(b)(2) and substitutes an election under section 338 by the acquirmg corporation to treat the acquired corporation ("target corporation") as if it sold all its assets on the stock acquisition date. Thus, this new provision does not eliminate the recapture of the investment credit attributable to the deened sale of assets by the target corporation. See TEFRA \& 224(b).

100. Property does not lose its status as section 38 property because of a inere change in the form of conducting the trade or business if the taxpayer retains a substantial interest in the trade or business and uses the property in that enterprise. See I.R.C. $\$ 47(b)(3)$ (West Supp. 1982). In addition, the IRS requires that, to avoid recapture, the basis of the property in the hands of the transferee be determined in whole or in part with reference to the property's basis in the hands of the transferor, Treas. Reg. $\$ 1.47-3(\mathrm{f})(1)(\mathrm{ii})(\mathrm{d})(1967)$, and that "[s]ubstantially all the assets (whether or not section 38 property) necessary to operate such trade or business are transferred to the transferee to whoin such section 38 property is transferred," Treas. Reg. $\S 1.47-3(\mathrm{f})(1)(\mathrm{ii})(\mathrm{c})$ (1967). Consequently, on incorporation of a going business, the taxpayer can avoid recapture only if he transfers to the new business all of the section 38 assets and substantially all of the nonsection 38 operating assets neccssary to conduct the new busines. See Rev. Rul. 514, 1976-2 C.B. 11 (recapture of credit because transaction is not mere change in form when dentist, in tax-free section 351 incorporation of dental practice, transferred to wholly owned corporation all his section 38 dental equipinent, but retained and leased to corporation building used in dental practice).

The requirement that the transferor inust retain an interest in the new corporation at least equal to his prior interest must be met each year until the expiration of the investment credit holding period. Thus, if his interest in a partnership were $5 \%$ and his interest in a newly formed corporation remained $5 \%$, no recapture occurs. If his interest in a later year should fall below $5 \%$, however, recapture would occur. See Treas. Reg. \& 1.47-3(f)(2), (5)(ii), (iv) (1967).

101. See, e.g., Long v. United States, 652 F.2d 675, 681 (6th Cir. 1981), rev'g 79-2 U.S. Tax Cas. (CCH) I 9612 (W.D. Tenn. 1979) (recapture, not niere change in form, on liquidation of subchapter $S$ corporation although former shareholders continued to hold assets and operate same business); Loewen v. Commissioner, 76 T.C. 90,95 (1981) (no recapture, only change in form, when farmers transferred section 38 property in tax-free section 351 incorporation although transfer of operating assets took the form of short-term oral leases); Ranum v. Coununissioner, 72 T.C. 671 (1979) (recapture, not inere change in form, on section 333 liquidation of a subchapter $S$ corporation); Hammerstroin v. Commissioner, 60 T.C. 167, 180 (1973) (no recapture on change of 
strengthened imvestment tax credit allege that the uncertainty and complexity stemming from the recapture rules are counterproductive to the effectiveness of the credit as a subsidy. ${ }^{102}$ They further claim that the pre-1981 recapture rules - those that required the property to have a useful life of at least seven years and then required the taxpayer to hold that property for at least seven years in order to obtain the benefit of the full $10 \%$ credit-discriminated against shorter-lived assets ${ }^{103}$ and discouraged replacement of obsolete business property held for less than the required seven year period. ${ }^{104}$

The ninety-seventh Congress responded to these criticisms by reducing the maximum period of exposure to recapture to five years for five, ten, and fifteen-year recovery property, and to three years for three-year recovery property. ${ }^{105}$ In addition, if a disposition occurs prior to the expiration of the full five-year period, only a pro rata portion of the credit remains subject to recapture. ${ }^{106}$ Thus, on five-year property, which produces either a $10 \%$ or an elective $8 \%$ credit, $20 \%$ of the full credit is deeined earned during each year the taxpayer holds the property. If the taxpayer disposes of five-year property without holdmg it the full five years, he can retain $20 \%$ of the initial credit for each full year he holds the property. Thus, if he disposes of five-year recovery property after he has held it a full two years, but less than three years, he can retain $40 \%$ of the origmal credit; $60 \%$ of the original credit is recaptured. ${ }^{107}$

ownership from community property to tenancy in common); Priv. Let. Rul. 8,103,001, 1981 Fed. Taxes: Priv. Let. Rul. (P-H) \ 186(81) (Jan. 23, 1981) (recapture, not mere ehange in form, where taxpayer in nontaxable section 351 incorporation transferred all section 38 business assets to corporation but retained busimess building constituting $38 \%$ of operating business assets for lease to corporation). But see Felgenhauer v. United States, 81-2 U.S. Tax Cas. (CCH) I 9532 (E.D. Wash. 1981); Ostheller v. United States, 81-2 U.S. Tax Cas. (CCH) If 9531 (E.D. Wash. 1981) (following Loewen, court determined that transfers of "substantially all" assets occurred on section 351 incorporation thereby constituting change in form only and requiring no reeapture).

102. See, e.g., Hearings on Investment Tax Credit, supra note 14, at 223, 266-7 (statements of Dale W. Wickham and Robert T. Benz).

103. Id. at 206 (statement of Prof. Brannon). The Treasury proposal in 1974-to eliminate the various useful life limitations and grant the full credit to all eligible property with a useful life of at least 3 years-would have eliminated all recapture. See id. at 170 (stateinent of Emil M. Sunley, Deputy Assistant Secretary of the Treasury for Tax Policy).

104. Id. at 266-67 (statement of Robert T. Benz).

105. ERTA § 211(g), (codified at I.R.C. § 47(a)(5) (West Supp. 1982)).

106. I.R.C. $\S 47(a)(5)(A)$, (B) (West Supp. 1982).

107. For discussion of a TEFRA provision requiring an upward basis adjustment upon disposition of certain section 38 property previously adjusted under I.R.C. $\$ 48(q)$ (1976 \& West Supp. 1982), see supra note 56. The amended provisions have decided economic advantages for qualified taxpayers. If, under prior law, a busimessman purchased $\$ 100,000$ of new equipment with a five-year useful life, producing a credit of $\$ 6666$, and if the equipment ceased to qualify after he held it for less than three years, the businessman would have to reeapture the entire $\$ 6666$. Those same facts would produce an initial elective credit of $8 \%$ or 8,000 and, on loss of eligibility during 


\section{INTRODUCTION OF AN "AT-RISK" CONCEPT TO THE INVESTMENT TAX CREDIT}

The achievements of the ERTA and the TEFRA in expanding the value of the imvestment tax credit as a subsidy are manifold: extending the credit to new types of property; enacting a simpler formula producing larger dollar benefits; ${ }^{108}$ and subjecting a smaller share of the credit to recapture should the taxpayer prematurely dispose of the property. Agamst these advances must be balanced a fundamentally new restraint on the use of the credit: the "at-risk" concept. The at-risk concept of section 465 was not new to the Code in 1981; what is new is its application to the investment credit. An examination of the at-risk concept's statutory origms and rapid rise to popularity as a weapon of choice against certam types of potential tax abuse can, therefore, aid in understanding why its recent extension to the investment credit field is not a satisfactory answer to problems of investment credit tax abuses.

\section{A. Origin of the "At-Risk" Concept of Section 465: Abuses of Tax Shelters.}

For as long as the maximization of after-tax net incoine lias constituted a fundamental objective of business enterprises, the Annerican taxpayer has sought to minimize his incoine tax expenses by obtaming tax preferences that either recharacterize his gross receipts, defer recognition of taxable receipts, or directly eliminate tax liability. Taxpayers often legitimately manipulate established primciples of federal taxation solely to obtain lucrative tax benefits that have no independent economic significance. Prior to 1976 , for example, a taxpayer miglit "invest" in an activity in order to become entitled to allowable deductions that created artificial tax losses. The taxpayer then used these losses to offset-and thereby shelter-other, unrelated taxable inconie. ${ }^{109}$

Professor Bittker has noted that the success of tax shelters stems largely from a basic structural element of the federal income tax system. Under the "global" approach of the rules of federal taxation, a taxpayer generally must aggregate all income as well as all deduc-

year three (after the businessman had held the property more than two years), the taxpayer could retain $40 \%$, or $\$ 3,200$, of the original credit and recapture only $\$ 4,800$. Current law would produce for him a permanent tax saving of $\$ 3,200$ over prior law.

108. The ERTA's experimentation with a technique to grant economic advantages eqnivalent to the credit to certain corporations that could not absorb a benefit structured as a tax credit also represented a substantial, though fleeting, benefit.

109. For a discussion of pre-1976 abuses, see Wiesner, Tax Shelters-A Survey of the Impact of the Tax Reform Act of 1976, 33 TAX L. REv. 5, 7-39 (1977). 
tions. ${ }^{110}$ This aggregation approach permits deductions allowed for investment expenses both to reduce the income derived from the imvestment and, if excess deductions exist, to spill over and reduce income derived from other sources. Although exceptions do exist, ${ }^{11}$ the global approach essentially permits mismatching of mcome and deductions, allowing an investor to shelter from taxation his otherwise currently taxable, high bracket income.

Prior to 1976 the most effective sheltering of income stemmed from the use of leveraged financing. By investing funds composed largely of borrowed money, a taxpayer could contribute a relatively nominal amount of his personal assets to an investment and still generate full tax benefits. The basis rules of the Code allowed the taxpayer to include the full amount of the indebtedness in his depreciation basis. ${ }^{12}$ Because any losses derived from an investment purchased with leveraged financing frequently exceeded the taxpayer's actual personal commitment, these losses arguably possessed no independent economic significance. The taxpayer, in effect, purchased artificial tax losses to spill over deductions to shelter unrelated income. Significantly, the benefits of leveraged financing accrued to the borrower of investment funds whether or not he assumed personal hability for the repayınent of the funds.

The Supreme Court, in Crane v. Commissioner, ${ }^{113}$ held that a taxpayer's depreciation basis in an investment or activity included the principal amount of any nonrecourse indebtedness secured only by the property purchased with the loan proceeds. The taxpayer in Crane inherited, operated, and eventually sold an apartment complex subject to a nonrecourse mortgage. She contended that because neither she nor the unrelated vendee assumed the inortgage, her amount realized was

110. See generally B. Bittker, Federal Taxation of Income, Estates and Gifts I 25.10.1, at 25-40 (1981). Prior to 1976, taxpayers could shelter their high bracket salaries or professional fees with excess deductions derived from investments in a wide variety of ventures:

railroad boxcars, secondhand computers, lithographs, video tapes, Mexican vegetables, and virtually anything else could serve as an investment vehicle, provided it crammed an abnormal ainount of deductions into the first year or two of the taxpayer's participation, usually by taking advantage of statutory provisions for the write-off or rapid depreciation or amortization of capital outlays.

Id.

111. Several specific exceptions limit the concept of "global" net income. For example, the tax laws segregate items of capital gains and losses and tax them differently from other income and expenses. See I.R.C. $\$ \S 1201-1223$ (West Supp. 1982). Moreover, certain "tainted" activities generate allowable deductions only up to an amount equal to the incoine they produce. See, e.g., I.R.C. $\$ 165$ (d) (wagering), $\S 183$ (hobbies), $\S 280$ A (vacation home rentals).

112. See I.R.C. $\$ \$ 1012-1019$ (West Supp. 1982).

113. 331 U.S. 1 (1947). 
only the net amount of cash that she received. ${ }^{114}$ The IRS countered with the argument that the value of the property Crane inherited and sold was greater than her equity in the apartment building and lot. ${ }^{115}$ The value of the property, according to the Service, was the fair market value of the lot and apartment building undiminished by the principal amount of the mortgage indebtedness. ${ }^{116}$ Crane, however, urged the Court to equate the meaning of the tern "property," as used in the taxing statute, with the accumulated equity in the physical asset. ${ }^{117}$ The Court rejected Crane's approach and, mstead, defined property as the actual physical asset over which the taxpayer exercised her ownership rights. ${ }^{118}$ In so holding, the Crane Court establislied a rule that, for purposes of computing gam, a taxpayer inust include the principal amounts of both personal obligations and nonrecourse indebtedness in the basis of his property.

By according umiform treatment to both recourse and nonrecourse liabilities, lowever, the Crane Court "laid the foundation stone of inost tax shelters."119 Judicial development of the Crane rationale eventually allowed the taxpayer to depreciate property from a basis in excess of the taxpayer's actual economic investment in the property. The Service attempted to limit the Crane holding, applying it only when the taxpayer inherited property subject to an unassumed mortgage, but the courts unwaveringly followed the broader Crane rationale. ${ }^{120}$ Eventu-

114. Id. at $3-4$.

115. Id. at 4-5.

116. Id.

117. Id. at 3 .

118. Id. at 10-11. Sound economic rationale supports the judicial equation of assumption of debt, in a purchase-sale situation, with payment of money. In a credit oriented economy, different treatment of these financing techniques would favor the tax-wise investor blessed with deep cash pockets. Consider, for example, taxpayer $A$ who purchases a building with $\$ 100,000$ cash and taxpayer B who purchases the same building by personally assuming a $\$ 100,000$ mortgage on the building. In view of the various holdings of the Supreme Court, both A and B have a basis of $\$ 100,000$ in the building for depreciation purposes (under old section $167(\mathrm{~g})$ and new section 168) and the seller in each instance has realized $\$ 100,000$ for purposes of section 1011. If the assumption of the mortgage by B were not treated as the equivalent of money, and had Mrs. Crane prevailed, B would have had a zero basis in the property and no amount to depreciate.

119. Bittker, Tax Shelters, Nonrecourse Debt, and the Crane Case, 33 TAx L. Rev. 277, 283 (1978).

120. The Tax Court, for example, in Bolger v. Commissioner, 59 T.C. 760 (1973), acq. 1976-1 C.B. 1, held that a taxpayer acquired a depreciable basis, equal to the full purchase price, in certain property even though he assumed no personal hability for any mortgage indebtedness. In Bolger the taxpayer ordinarily invested by (1) forming a noininally capitalized "financing corporation;" (2) causing it to purchase commercial real property that a commercial user desired to lease; (3) causing the corporation to enter into a net lease with the user; and (4) causing the corporation to sell its negotiable corporate notes, secured by mortgages on the leased property, to an institutional lender pursuant to a note purchase agreeinent. The taxpayer then purchased the property froin the corporation for a nominal consideration, without assuining any personal liabil- 
ally the taxpayer could include in the basis of acquired property the principal amount of any purchase-money indebtedness or the full market value of property subject to indebtedness regardless of the taxpayer's personal liability to repay the borrowed funds. By making only a nominal out-of-pocket investment in a venture, taxpayers who sought to shelter unrelated incoine could generate artificially high amounts of allowable deductions, as well as spill-over losses.

The classic tax shelter investment after Crane involved three beneficial elements for a taxpayer: (1) deferral of taxable gain; (2) conversion of ordmary income into capital gain; and (3) leverage, particularly leverage without the taxpayer's personal liability to repay the borrowed funds. ${ }^{121}$ In 1976, Congress enacted section 465 to attack only the third element, the use of leverage. ${ }^{122}$ Congress correctly focused on leverage because the use of indebtedness-whether recourse or nonrecourse-to leverage a taxpayer's investment permits him to realize inore tax benefits than would be possible if he personally financed the entire venture. The taxpayer, for example, may deduct allowances for depreciation and other noncash expenses that often greatly exceed his personal investment and that are more than sufficient in ainount to defer the venture's tax liabilities. In response to such situations, section 465 simply restricts the spill-over of certain deductions in excess of the income derived from the venture and thereby prevents the sheltering of unrelated income. Under section 465 , only losses incurred in an activity in which the taxpayer risks a genuine economic investment may be used to shel-

ity. The Commissioner sought to deny the taxpayer any depreciation deductions on the property, but the court held that the taxpayer's depreciable basis equalled the full purchase price even though the taxpayer had no personal liability for the mortgage indebtedness. In holding for the taxpayer, the Tax Court rehed principally on the Crane decision and its own decision in Mayerson v. Commissioner, 47 T.C. 340 (1966), acq. 1969-1 C.B. 21, which had reaffirmed the Crane theory that basis of depreciable property should include the amount of any unassumcd mortgage on the property. See also Blackstone Theatre Co. v. Commissioner, 12 T.C. 801 (1949) (depreciable basis of property includes full amount of unassumed outstanding tax liens and penalties).

The judicial decision that comes closest to questioning the Crane doctrine is Estate of Frankhin v. Commissioner, 64 T.C. 752 (1975), affd, 544 F.2d 1045 (9th Cir. 1976). The Tax Court faced contrived real estate transactions in which the taxpayer computed depreciable basis on the sum of his cash investment and his allocable portion of a partnership's nonrecourse debt. The court held that, because of its indefinite and unconditonal nature, the partnership's indebtedness was not includable in the basis of the property. The court, however, distinguished Crane, Mayerson, and Bolger by focusing on the transaction's lack of economic substance. Because the transaction's "purported initial sales price" was unrelated to the fair market value of the property, the possibility of overvaluation of the property clearly influenced the court's analysis. See id. at 771 .

121. See H.R. ReP. No. 658, 94th Cong., 1st Sess. 25-27 (1975); Schapiro, Limitation of Losses to Amount at Risk, in TAX Shelters AFTER TAX REFORM 1 (R. Schapiro, ed. 1977).

122. Tax Reform Act of 1976, Pub. L. No. 94-455, $\S 204,90$ Stat. 1520, 1531 (codified at I.R.C. $\S 465$ (1976 \& West Supp. 1982)). 
ter otherwise taxable unrelated income. ${ }^{123}$ Thus, under section 465 the taxpayer's "amount-at-risk" (AAR) in a venture limits tlie amount of losses that may offset and shelter income derived from an unrelated venture.

\section{B. Extension of the "At-Risk" Concept to Section 46(c)(8): Potential for Additional Abuse.}

Since its enactment in 1962, the investment tax credit lias provided opportunities for manipulation equal to those provided in the traditional Crane-derived shelter. Cost recovery allowances (depreciation) and investment credits are both important as incentives for government-favored activities. Congress has frequently considered the concepts in tandem when analyzing the economic impact of alternative revisions of its fiscal pohicy. ${ }^{124}$ Participants in tax-shelter schemes, moreover, draw hittle distinction between different forms of tax benefits when net tax reduction is their prime reason for mvolvement. Clearly, by continuing to overlook the shelter potential of a tax credit, the ninety-seventh Congress would have again illustrated an unfortunate tendency toward "form over substance."

In enacting the imvestment credit revisions of the ERTA, however, Congress focused on more than just those evils traditionally associated with nonrecourse leveraged financing; it also clearly recognized and sought to attack the problem of overvaluation of property acquired to obtain an inflated investment credit. ${ }^{125}$ Prior to the ERTA, according to comments in its legislative history, ${ }^{126}$ an unscrupulous purchaser of eligible property worth only twenty dollars could agree to pay the seller of the property its real worth in cash and to encumber tlie property

\footnotetext{
123. See B. BITTKER, supra note 99 , I 25.10.3.
}

Section 465 is not the only tax shelter weapon used by the Service. Section 6659, for example, provides substantial penalties for the over-valuation of assets, formerly possible by the use of nonrecourse financing. See I.R.C. $\S 6659$ (1976 \& West Supp. I982). The Code provides civil and criminal penalties for offenses related to the willful failure to pay taxes or for any attempt to evade or defeat any tax imposed by the Code. See, e.g., I.R.C. $\$ 7201$ (1976). In addition, the Service has issued Revenue Rulings that accurately attack abusive tax shelters. See, e.g., Rev. Rul. 69, 1980-1 C.B. 55 (charitable deduction allowable to extent of fair market value of contributed property rather than an artificially calculated estimate of value); Rev. Rul. 73, 1980-1 C.B. 128 (amount of nonrecourse notes payable only to the extent of proceeds received from sale of minerals held nondeductible as advance mineral royalties); Rev. Rul. 74, 1980-1 C.B. 137 (formation of foreign trust by American citizen held sham transaction thereby disallowing trust expenses).

124. See, e.g., TEFRA, supra note 2, at 481-82 (reenactment of basis adjustment feature coupling ACRS and investment credit benefits); see also supra note 15.

125. See Staff of Jolnt Comm. on Taxation, 97th Cong., Ist Sess., Proposed Depreclation and Investment Tax Credit Revisions Part III: analysis of Specific Issues 52 (Comm. Print 1981).

126. $1 d$. 
with a nonrecourse note for eighty dollars. The seller "ideally" would accept the original twenty-dollar cash "downpayment" and disregard, under an installment sales privilege, the eighty-dollar nonrecourse imdebtedness until receipt. ${ }^{127}$ Payment of the debt might constitute an unexpected taxable windfall, but default certainly would not economically injure the seller. Under the fully evolved Crane doctrine, ${ }^{128}$ the purchaser could include in the basis of the property the twenty dollars cash as well as the ineaningless eighty-dollar nonrecourse habihty and benefit by receiving depreciation and investment credit allowances computed on an inflated hundred-dollar basis. Obviously the sole purpose of this nonrecourse indebtedness was to generate an apparent purchase price of one hundred dollars rather than twenty dollars and thus artificially inflate depreciation and investment credit allowances.

Faced with stern Treasury reaction to the possibility of such unconscionable garnerings of government subsidies, ${ }^{129}$ Congress took action to limit such abuse. As part of the ERTA, it incorporated by broad reference the section 465 at-risk restrictions on losses into the new investment credit provisions. ${ }^{130}$ Section $46(\mathrm{c})(8)$ thus generally denies the investment credit subsidy for otherwise eligible property that a taxpayer acquires with funds borrowed on a nonrecourse basis.

\section{COMParing the Operation OF AT-Risk Limitations UNDER SECTION 465 AND UNDER SECTION 46(C)(8)}

The incorporation of any anti-abuse provision into a tax incentive program such as the investment credit will mevitably cause some foreseeable technical problems. But unexpected discrepancies as well are beginning to surface in the application of the at-risk test derived from section 465 . The inost striking problem arises because the ninety-seventh Congress apparently accepted the position of the Treasury that the use of nonrecourse financing in the acquisition of section 38 property should usually operate per se to deprive a taxpayer of the privilege of the investment credit. Thus, section 46(c)(8) initially denies any investinent credit to a taxpayer for property purchased with borrowed funds that the taxpayer is not personally obhigated to repay, even though section 465 , the parent provision of the at-risk concept, generally does not

127. See I.R.C. $\S 453$ (1976 \& West Supp. 1982).

128. See supra text accompanymg notes 113-19.

129. See, e.g., Hearings on Investment Tax Credit, supra note 14, at 181-82 (statement of Jerome Kurtz, Commissioner, Internal Revenue Service); 55 J. TAx'N 389 (1981) (remarks by Commissioner Egger before Heart of America Tax Institute in Kansas City).

130. ERTA § 211(f), (codified at I.R.C. $\$ 46(c)(8)$ (West Supp. 1982)). 
deny deductions for expenses in the same venture to the saine taxpayer using the same nonrecourse financing.

\section{A. Taxpayers Subject to the At-Risk Test.}

With two exceptions, all taxpayers must face the at-risk tests under both section $46(c)(8)$ and section 465 of the Code regardless of the nature of their business or their imvestment. The exceptions, however, are major: the first is based on the legal structure of the taxpayer, and the second is based on the activities the taxpayer engages in. First, Congress granted immunity from at-risk requirements to any corporation that is not closely held, regardless of the nature of its business or investment activities. The Code does not expressly provide this immunity for publicly held corporations, but it necessarily confers it by not including them within the ambit of section $465(a)(1),{ }^{131}$ and thus not within section 46(c)(8). Section 465(a)(1) covers individuals, subchapter $S$ corporations, and, simce 1978, certain closely-held corporations. ${ }^{132}$

The closely-held corporations that automatically fall within the net of section 465, and therefore within the at-risk restrictions of the investinent credit, are those that meet the stock ownership threshold requirements for personal holding company status. ${ }^{133}$ If a corporation is held through such stock ownership, it faces the at-risk requirements even though it may, in fact, operate as a legitimate active business rather than as a personal holding company. Under these rules, if five or fewer individuals directly or indirectly own more than fifty percent of the value of the corporation's stock during the last half of its taxable year, the corporation is subject to the at-risk requirements. ${ }^{134}$ If less

131. The limitation of the investment credit to the amount at risk applies only to taxpayers "described in section 465(a)(i)." I.R.C. § 46(c)(8)(A)(i) (West Supp. 1982).

132. Under I.R.C. section 641(b) an estate or trust receives the same tax treatment as does an individual. Professor Bittker has commented that the 1978 extension of the at-risk provisions to closely held corporations was "an innovation in the jurisdictional reach of provisions designed to curb tax avoidance." See BITTKER, supra note 110, at 25-43.

133. These requirements are established in section $542(a)$ and invoked by section $465(a)(1)(C)$.

134. I.R.C. section 544 (1976) now determines the attribution rules for stock ownership under section 542. Until 1978, the attribution rules of section 318 applied to the constructive ownership of the stock under section 542(a)(2) in determining whether the corporation was subject to section 465. Congress decided in 1980 that the section 318 attribution rules were too narrow for purposes of section 465 in several respects. For example, under section 318 , an individual is deemed to own only the stock of his spouse, children, grandchildren, and parents. In contrast, under section 544, an individual is deemed to own the stock owned by his spouse, ancestors, lineal descendants, and brothers and sisters. Under section 318 , the stock of a subsidiary corporation is deemed owned by a shareholder of a parent corporation only if that shareholder owns $50 \%$ or more in value of the stock of the parent. By contrast, under section 544, stock in a subsidiary owned by a parent corporation is attributed to all of the shareholders of the parent in proportion to each shareholder's stock ownership of the parent. Congress determined that the section 318 attribution rules 
than ten individuals own all the stock of a corporation, the corporation is automatically subject to the at-risk requirements because five or fewer stockholders will unavoidably own more than fifty percent of the stock. If ten or nore individuals own all the stock, or if the stockholders include trusts, estates, partnerships or other corporations, then the personal holding company attribution rules ${ }^{135}$ must be explored to determine if the stock-although owned of record by various apparently unrelated stockholders-inight be imputed to one or inore stockholders under the constructive ownership rules applicable to personal holding companies. ${ }^{136}$ Thus, because of the enactinent of the ERTA closelyheld corporations that conduct active busmesses, and that lave never previously faced personal liolding company stock ownerslip rules, may have to examine these rules before acquiring eligible section 38 property. At the other end of the spectrum, publicly lield corporations will, in all likelihood, escape the personal loolding coinpany stock ownership test and operate free of the at-risk restrictions.

The second exemption from the at-risk restrictions involves two specific taxpayer activities. The at-risk provisions of the Code impose no limitations on taxpayers, regardless of legal structure, engaged in "the holding of real property (other than mineral property)," 137 nor on closely-held corporations engaged in certain qualified equipment leasing. ${ }^{38}$

could inadvertently exempt from the at-risk limitations of section 465 a corporation that would in fact be a personal holding company if the strict attribution rules of section 544 were applied, but would not be a personal holding company under section 318 attribution rules. Congress also noted that under section 318, stock of a subsidiary, even though wholly owned, would not be considered more than $50 \%$ owned by five or fewer individuals under the personal holding company stock ownership test if no individual was considered to own $50 \%$ or more of the stock of the parent corporation. In order to include such corporations within the scope of section 465 , Congress replaced the attribution rules of section 318 with those of section 544 for all purposes of section 465 with one exception: the section 544 attribution rules between partners-attributing stock of a corporation owned by one partner to another partner-do not apply under section 465 . See S. ReP. No. 498, 96th Cong., 2d Sess. 42, reprinted in 1980 U.S. CODE CoNG. \& AD. NEws 316, 353-54.

135. See generally Treas. Reg. § I.544-I, T.D. 6739, 19642 C.B. 156.

136. See I.R.C. \& 544(a) (1976 \& Supp. IV 1980).

137. I.R.C. $\S 465$ (c)(3)(D) (Supp. IV 1980). This section treats personal property and services that may be incidental to making real property usable as living accommodations as part of the exempt real estate activity. For example, owning and operating a hotel qualifies as an exempt real estate activity free from the at-risk restrictions of section 465 . One cavcat exists: the real estate exclusion does not apply to taxpayers holding real estate in any of the five objectionable activities enumerated in section 465(c)(I). See infra notes $139-41$ and accompaning text.

138. See I.R.C. \& 465(c)(4) (Supp. IV 1980). "Equipment leasing" includes the leasing, purchasing, servicing, and sellimg of section 1245 property, such as computers (including computer software); transportation equipment (airplanes, automobiles, tractors, and railroad cars); copiers and calculators; heavy equipment like cranes; furniture; and similar property. I.R.C. $\S 465(c)(6)(A)$, (B) (Supp IV 1980). The statute is not intendcd to include master sound recording 


\section{B. Activities Covered by Section 465 At-Risk Provisions.}

Categorization by taxpayer activity provides one current format for the limited exceptions to the at-risk requirements described above. It also serves as the historical format of section 465 . Section 465 originally affected only taxpayers engaged ${ }^{139}$ in one of five specifically enumerated objectionable activities: 1) holding, producing or distributing motion picture films or videotapes; 2) farming; ${ }^{140} 3$ ) leasing certain section 1245 property; 4) explorimg for or exploiting oil and gas resources; and 5) exploring for or exploiting geothermal deposits. ${ }^{141}$ Although Congress enacted section 465 in 1976 as a narrowly aimed anti-tax shelter device, ${ }^{142}$ within two short years Congress reversed this situation and applied the section generally to all activities-whether or not statutorily enumerated-conducted by any covered taxpayer in any trade, business, or imvestment for the production of income. ${ }^{143}$ The only exceptions are for real estate holdings and certain equipinent leasing. ${ }^{144}$

Despite this broad potential scope, section 465 actually has a narrow operative thrust. The at-risk limitations themselves operate within the framework of separate "activities," a word which is a term of art. ${ }^{145}$ Section 465 has no operative effect when a taxpayer engages in only one activity. The section does come imto play when a taxpayer attempts to apply a net loss from one activity as a deduction against incoine

leases and other contracts relating to literary, artistic or musical properties, such as books, lithographs of works of art, and musical tapes. See JoINT COMMITTEE ExPLANATION OF 1978 ACT, supra note 40, at 135. An equipment leasing corporation must also meet certain additional tests in order to qualify for this exception from the at-risk restrictions. For a general discussion of the evolution of this portion of section 465, see S. REP. No. 498, 96th Cong., Ist Sess. 44-45, reprinted in 1980 U.S. CODE CONG. \& AD. NEwS, 316, 355-56.

139. The activity is "engaged" in when it is undertaken for the production of income, or as a trade or business, not a hobby. I.R.C. $\$ 465$ (c)(1) (1976).

140. The Code broadly defines the objectionable activity of "farming" as "the cultivation of land or the raising or harvesting of any agricultural or horticultural commodity including the raising, shearing, feeding, carmg for, training, and management of animals." I.R.C. § 464(e) (1976). The raising of fruit-bearmg and nut-bearing trees is withm the suspect activity. Other trees, however, are not agricultural or lorticultural commodities, and, therefore, are outside the definition of "farming." Id.

141. For explicit development of the definition of this activity, see I.R.C. § 613(e)(3) (Supp. IV 1980).

142. See Tax Reform Act of 1976, Pub. L. No. 94-455, § 204, 90 Stat. 1520, 1531 (codified in scattered sections of I.R.C.).

143. Revenue Act of 1978, Pub. L. No. 95-600, $\$ 201,92$ Stat. 2763, 2814 (codified in scattered sections of I.R.C.).

144. Although the holding of real property need not meet the at-risk limitations of section 465 , this exclusion does not operate for real property lield as an integral part of any one of the five activities specified in section $465(\mathrm{c})(1)$; it applies only to real property lield im one of the nonspecified activities referred to in section 465(c)(3)(A). See I.R.C. $\$ 465$ (c)(3)(D) (Supp. IV 1980) (introductory clause).

145. See B. BitTker, supra note 110, I 25.10.2; see also Proposed Treas. Reg. $\$ 1.465-1$ (1979). 
derived from other activities. Section 465 allows this net loss to shelter incoine derived from other activities only in an amount equal to the taxpayer's at-risk investment in the loss-producing activity. ${ }^{146}$ Deductible expenses incurred in a single activity are fully allowed up to the amount of income produced by that activity and any excess deductions-when that single activity constitutes a taxpayer's sole activitywill produce net losses that carry over to other taxable years without any section 465 ceiling or any concern with the amount the taxpayer has at risk in that activity. 147

Because section 465 operates only when excess deductions from one activity are used as deductions to offset income of another activity, the applicability of the section's rules turns, in part, on the existence of a "separate activity" and whether a series of business or investment transactions will be viewed as a "separate activity." Congress originally specified that each of the activities listed in section 465(c)(1) constitutes a separate activity. ${ }^{148}$ Thus, section 465 treats each film or videotape, each leased section 465 property, eacli farm, each oil and gas property, and each geothermal property as a separate activity. When the Revenue Act of 1978 extended the scope of section 465 to "each activity" conducted by a taxpayer in carrying on a trade or business or for the production of income, ${ }^{149}$ however, Congress did not prescribe new guidelines to separate one activity from another under the added coverage.

The consequences of separate activity treatınent are often significant. For example, if a taxpayer owns two ice cream parlors-one operatimg unprofitably in a downtown area and one operating at a profit

\footnotetext{
146. See Proposed Treas. Reg. § 1.465-2 (1979).

If a taxpayer invests $\$ 15,000$ cash and $\$ 85,000$ for which he is not at risk in a covered activity, his amount at risk would equal only $\$ 15,000$. Assume that, during the taxable year, the covered activity (one of several investment activities) produces income of $\$ 20,000$ and otherwise allowable deductions of $\$ 45,000$. The taxpayer's loss attributable to that activity equals $\$ 25,000$ : $\$ 45,000$ of deductions offset by $\$ 20,000$ of income earned by the activity. To the extent that the taxpayer wishes to use the $\$ 25,000$ loss-referred to as the section 465(d) loss, see Proposed Treas. Rcg. \$ 4.465-11(a)(2) (1979)-against income derived from his other activities, the section 465 limitation comes into play. If, at year's end, the amount the taxpayer has at risk remains only $\$ 15,000$ the taxpayer may utilize only $\$ 15,000$ of the $\$ 25,000$ section 465 (d) loss as a deduction against his income from other activities. The remaining $\$ 10,000$ of the loss is not allowable as a deduction in the same taxable year because it exceeds the amount at risk. It is, however, treated as a deduction allocable to the original activity for the next succeeding ycars. See I.R.C. § 465(a)(2) (Supp. IV 1980); Proposed Treas. Reg. $\$ 1.465-11$ (a)(2).

147. Thus, even if a taxpayer has nothing at risk in an activity, otherwise allowable deductions of $\$ 20,000$ allocable to the activity, and $\$ 15,000$ of income from the activity, a full $\$ 15,000$ deduction will be allowed. See Proposed Treas. Reg. \& 1.465-11(c) (1979).
}

148. I.R.C. § 465(c)(2) (1976).

149. See Revenue Act of 1978, Pub. L. No. 96-600, $\$ 201$ (a), 92 Stat. 2763, 2814 (codified at I.R.C. $\S 465(c)(3)$ (Supp. IV 1980)). 
in the suburbs-and if the operation of the two stores constitutes a single activity, he could apply the excess deductions from the downtown parlor against the incoine derived from the suburban parlor regardless of whether he had any amount at risk in either location. Under section 465 , the taxpayer has not actually spilled over any excess deductions froun the aggregated ice cream parlor activity to another separate activity. If each parlor were viewed as a separate activity, however, excess deductions from the downtown parlor could shelter income derived from the suburban operation only in an amount equal to the taxpayer's at-risk investment in the downtown parlor's activity.

The separate activity approach of section 465 represents a departure from established canons of taxation. The Code ordinarily aggregates moome from all sources and allows deductions and credits against this analgamated whole. Witlout doubt, manipulation of the system by those claiming excessive artificial deductions justifies the separate activity treatment of section 465 . However, because the separate activity approach represents an exception to the norm and imposes special burdens on taxpayers and the IRS alike, Congress only cautiously expanded the concept when it extended the general scope of section 465 . Favoring the taxpayer, Congress establislied a presumption that those activities-newly covered in 1978 by section 465 - constituting a taxpayer's bona fide trade or busmess, as distinguished from an investment, are deemed a single aggregated activity, as long as the taxpayer actively participates in the management of that trade or business. ${ }^{150}$ Thus the ice cream parlor owner could treat his two stores as a single aggregate activity under section 465 if le actively participates in the inanagement of both stores. Even if the aggregate deductions exceed the aggregate income of the presumed single umbrella activity, the atrisk restrictions of section 465 do not come into play when the taxpayer does not use the excess deductions to shelter unrelated income derived from another activity. ${ }^{151}$

150. See I.R.C. $\$ 465(c)(3)(B)$ (West Supp. 1982); Joint Committee Explanation of 1978 ACT, supra note 40 , at 131 .

151. Although Congress designed the aggregation of activities rule to provide adequate protection for taxpayers who actively participate in the inanagement of a trade or business, this concept has proved deficient in several respects. First, the aggregation rule applies only to nonenumerated activities within a single trade or business. A taxpayer nay not aggregate activities of different trades or businesses even though he actively participates in the management and operation of both businesses. Thus the owner of a group of ice cream parlors may not aggregate his ice cream activities with a retail clothing business even though he is an active participant in both. Second, the aggregation rule offers no rehef to the active participant in a bona-fide trade or business who realizes losses from the legitimate business endeavor but derives income from other sources. An owner of two ice creain parlors may offset incoine derived from other sources only 
The determmation of whether a taxpayer actively participates in the operation or management of a trade or business will vary with the circumstances. ${ }^{152}$ The legislative history of the Revenue Act of 1978 mentions various factors, both positive and negative, which should be considered. ${ }^{153}$ Congress also gave the Secretary of the Treasury discretion to prescribe regulations under section 465 contaming more specific standards by which one trade or business activity might be segregated into separate activities, or under which several activities might be aggregated into one activity for loss purposes. ${ }^{154}$ The House Report, however, indicates that Congress assumed that tax shelters are more likely to take the form of a passive imvestment than that of an active trade or business. ${ }^{155}$ In the absence of regulations, therefore, section 465 presumes that each investment constitutes a separate activity. ${ }^{156}$ Investments cannot be aggregated, and excess deductions from one investment activity can reduce mcome derived from any other source only up to the amount the taxpayer has at risk in that isolated investment activity.

\section{The Amount At Risk for the Investment Credit Is Measured Not By Activity, But By Property.}

The ninety-seventh Congress incorporated the at-risk limitations into the investment credit area by express cross-reference to section 465. These new at-risk rules apply to section 38 property "used in con-

with the ice cream losses that do not exceed his amount at risk in the ice cream business, even though he spends most of his time managing and operating a bona-fide ice cream business.

152. When a partnership or subchapter $S$ corporation carries on a trade or business in one of the non-enumerated activities, the key test in order to determine if several activities constitute one trade or business activity is whether at least $65 \%$ of the losses of the entity in the taxable year are allocable to persons actively participating in the management of the trade or business. See JoINT Committee Explanation of 1978 ACT, supra note 40, at 131.

153. Evidence of active taxpayer management includes "participating in the decisions involving the operation or management of the trade or business, actually performing services for the trade or business, or hiring and discharging employees (as compared to only the person who was the manager of the trade or business)." Id. Factors indicating a non-active role include "lack of involvement in management and operation of the trade or business, having authority only to discharge the manager of the trade or business, or having a manager of the trade or business who is an independent contractor rather than an employee." $I d$.

154. See I.R.C. $\$ 465(c)(3)(C)$ (1976 \& Supp. IV 1980). The Secretary has not to date exercised his discretion to alter the statutory presumption that an actively managed trade or business constitutes one section 465 activity. The proposed regulations, for example, state that the term "activity," unless expressly provided otherwise, refers only to an activity that is one of the five tax shelter activities enumerated in the Code and that, unless otherwise stated, "it is assumed that an entity conducting an activity is engaged only in that onc activity." Proposed Treas. Reg. $\$ \$ 1.465-$ 9(c), (d), FeD. TAXEs (P-H) I 20,648.39 (1979).

155. See Joint Committee Explanation of 1978 Act, supra note 40, at 132.

156. See H.R: Rep. No. 1445, 95th Cong., 2d Sess. 244 (1978). 
nection with an activity with respect to which any loss is subject to limitation under section 465." 157 Accordingly, the basis of affected section 38 property, which the Code ordinarily uses to compute the taxpayer's "qualified investment," 158 generally "shall not exceed the amount the taxpayer is at-risk with respect to such property as of the close of the taxable year."159 By limiting the "qualified investment" to the taxpayer's amount-at-risk, the new rules effectively limit the available credit.

In some aspects, both of the Code's at-risk provisions operate similarly. The same taxpayers are subject to the at-risk concept under both section 465 and the investment credit area. The section 465 exception for widely-held corporations, as distinguished from closely-held corporations, also applies in the investınent credit area. ${ }^{160}$ Finally, taxpayers who engage in exempt activities as defined in section 465 can acquire section 38 property and obtain a credit therefor without the burden of the new at-risk limitations in the investinent tax credit section.

The new at-risk investinent credit limitation, however, differs inarkedly froin section 465 in structure and causes adverse tax consequences even for a single-activity taxpayer. Although section 46(c)(8)(B) states that "at-risk" has the same ineaimig for investment credit purposes as it has in section 465 , section 465 is loss and activity oriented, coming into play only when certain excess deductions occur. The investunent credit provisions, on the other hand, are property-oriented, operating to deny the investment credit even when no loss occurs. The new at-risk basis limitation applies if a taxpayer uses section 38 property in an activity im which, had the activity actually generated a loss, the loss would have been "subject to limitation under section 465." 161 Even when the taxpayer's affected activities operate at a handsoine profit and do not produce excess deductions that would be subject to section 465 limitation, the lack of at-risk investınent in acquired property generally demies him an otherwise appropriate credit. This demial occurs even on acquisition of investment property by the most legitimate of businesses for an activity lacking any characteristics of tax shelter abuse.

Thus, section 46(c)(8), in effect, operates to deny the credit to the taxpayer based on the taxpayer's initial financing arrangeinents for eligible property. The legislative history corroborates this conclusion by

157. I.R.C. § 46(c)(8)(A)(ii) (West Supp. 1982) (emphasis added).

158. See supra notes $44-65$ and accompanying text.

159. I.R.C. $\& 46$ (c)(8)(A) (West Supp. 1982) (emphasis added).

160. See supra text accompanyiug notes 131-36.

161. I.R.C. \& 46(c)(8)(A)(ii) (West Supp. 1982). 
stating that "[t]he investment credit is not allowed for amounts invested in qualifying property to the extent the invested amounts are not atrisk." 162 The Senate Report notes that "amounts at-risk with respect to qualifying property are only those amounts considered at risk under section 465 that are directly attributable to investment in the property." 163 Thus, if the taxpayer contributes cash to an operating account of his business that would, under section 465 , be considered an at-risk investment in the busmess, that same cash would, under section 46(c)(8), fail to qualify as an at-risk investment in section 38 property. ${ }^{164}$ The theoretical imperfection of the extension of the at-risk concept, however, lies not so much in section 46(c)(8)'s preoccupation with the amount at-risk in the property, but rather in its failure to parallel the two-stage pattern of section 465 . By denying the investment credit at the outset, the new rules gloss over the two-stage distimction carefully developed during the evolution of section 465 . At the first stage, section 465 allows deductions in an originating activity up to the amount of the income derived from that activity regardless of the taxpayer's amount at risk. The second stage allows the transfer of cxcess deductions froin the origimating activity to reduce income derived from another separate activity only up to the taxpayer's amount-at-risk in the originating activity.

The ice cream parlor enterprise that was never intended as a tax shelter vividly illustrates the disparate results of the activity approach of section 465 as compared to the property approach of section $46(c)(8)$. Section 465 allows the taxpayer to aggregate his entire ice cream business into one activity, so long as le actively participates in its management. ${ }^{165}$ Consequently, he could not only benefit from the ordmary "first stage" deductions, which reduce the income of eacli respective sub-activity (the individual parlors), but lie could also use any excess deductions freely throughout the entire ice creain operation regardless of his amount-at-risk in any sub-activity. The property-by-property approach of section $46(\mathrm{c})(8)$ produces completely different tax consequences. Focusing on the nature of the financing used to acquire each freezer, soda fountain, or other particular item of section 38 property, and assuming a zero amount at risk, section $46(\mathrm{c})(8)$ would provide neither a "first stage" investment credit available to reduce the tax liability of a particular sub-activity nor the benefits of an analogous, yet property-oriented, aggregation concept. This severe curtailment of the

162. Joint Committee EXPLANATION of ERTA, supra note 38, at 96.

163. SenATE Report on ERTA, supra note 1, at 66 (emphasis added).

164. See id.

165. See supra text accompanying notes 148-56. 
investment subsidy is difficult to understand, especially in light of the parent provision's two-stage liberalization in 1978.166

With eligibility for the credit benefits turning solely on the nature of the initial financing used to acquire the property, section 46(c)(8) disregards both losses, the sine qua non for invoking the ceiling of section 465, and income. Several existing sections of the Code, which disallow only deductions in excess of an activity's income, suggest that section $46(c)(8)$ is overly liarsli and provide persuasive precedent for adoption of a two-stage approach. For example, a taxpayer engaged in a non-profit-making hobby may deduct all expenses of the liobby up to an amount equal to the income it produces. ${ }^{167}$ Objections ste1n not from the first stage of deductions covered by the liobby incoine, but from any second-stage attempt to carry hobby losses outside that activity to reduce income from other sources. A taxpayer raising parakeets for the joy of it can exhaust all parakeet income with parakeet expenses and pay no tax on the activity. Not so with the farmer who lias taxable farm income of $\$ 100,000$, and buys a $\$ 25,000$ tractor under a financing arrangement that produces no at-risk investment in the tractor by section $46(\mathrm{c})(8)$ standards. Because there is no at-risk investment, the farmer cannot realize a benefit by applying the investment credit against his farm income tax.

Another example of a two-stage income ceiling is the limit on deductions a taxpayer may take in connection with his vacation home. ${ }^{168}$ If, for instance, the taxpayer uses the home as a residence and also rents it to others, he can deduct those expenses properly allocable to the rental activity, but only up to the amount of the year's rental incoine. ${ }^{169}$ Only personal expenses are denied. ${ }^{170}$ The broad principle that tax preferences are not inherently suspect, and should meet witl no disallowances if applied only to the income of the activity originating the preferences, is mamifested again in the tax treatment of gainblers. Even wagering losses are allowed to the extent of wagering income. ${ }^{171}$ Why should the farmer who buys a tractor fare more poorly than the gambler?

The present investment credit at-risk restrictions, with their property-by-property approach, resemble but are even stricter than the original section 465 , whicll focused on only five suspect tax abuse

166. See id.

167. See I.R.C. \& 183 (1976); Treas. Reg. § 1.183-1(b) (1976).

168. See I.R.C. \& 280A (1976 \& Supp. IV 1980).

169. See Proposed Treas. Reg. $\& 1.280 A-3$, FeD. TAXES (P-H) ף 16,979.18-C (1980).

170. See Proposed Treas. Reg. \& 1.280A-1, FED. TAXES (P-H) \ 16,979.18-A (1980).

171. See, e.g., I.R.C. $\$ 165$ (d) (1976). 
activities. ${ }^{172}$ The section 465 regulations provided, for example, that if a taxpayer holds, produces or distributes motion picture films, each film represents a separate activity giving rise to a separate determmation of the at-risk investment in that film. ${ }^{173}$ Although the regulations apply this approach to other enumerated tax abuse activities, such as "leasing section 1245 property,"174 they also suggest possible modifications of the separate property approach. If, for instance, several section 1245 properties, such as parts of a computer system, constitute one unit under the saine lease, and are not separately financed or subject to different lease terms, the regulations aggregate the several properties for purposes of measurmg at-risk investinent. ${ }^{175}$

The legislative history of section 46(c)(8), however, does not suggest aggregation of section 38 properties, even if acquired by a single, legitimate, active busmess. Under the statutory structure, the volume and complexity of the records required to manage separate individual investments in eligible properties are awesome to contemplate. In view of the role of the investment credit as a congressionally-endorsed subsidy, it is difficult to find a rationale for the per se denial of the investment credit solely on the basis of the initial financmg of the section 38 property when that property is acquired in a non-tax-sheltermg active trade or business. ${ }^{176}$ The denial seems even less rational when examined in light of the vagaries of the calculations used to decide the amount-at-risk in a property.

172. See I.R.C. $\S 465(c)(1)(1976)$.

173. See Proposed Treas. Reg. § 1.465-42(c)(1), Fed. TAxes (P-H) I 20,648.72 (1979).

174. See Proposed Treas. Reg. \& 1.465-44(c)(1), FED. TAXES (P-H) T 20,648.74 (1979), which incorporates the rules of Proposed Treas. Reg. \& 1.465-42(c), FED. TAXES (P-H) I 20,648.72 (1979).

175. See Proposed Treas. Reg. \& 1.465-44(c)(2), Fed. TAXEs (P-H) \ 20,648.74 (1979).

176. Section 46(c)(8)'s per se denial of an investment tax credit based solcly on the use of nonrecourse financing threatens the current inportance of this type of financing. Individuals and closely held corporations conducting only one trade or business-and consequently rcalizing income from only that trade or business-face a distinct disadvantage in competing with publicly held companies. For example, under current economic conditions, many manufacturers of heavy equipment offer special financing arrangements to increase sales. A small cash down payment coupled with a nonrecourse note for the balance of the sales price, secured only by an interest in the equipment, disqualifies the individual or closely held corporate purchaser from much of the mvestment tax credit benefits. The purchaser could claim a credit for only part of the nominal down payment, even though he uses the equipment in a profitable, bona-fide business that he actively manages. A publicly held corporate purchaser could claim a credit equal to a percentuge of the entire purchase price. Thus, the publicly-held purchaser can obtain the same equipment at a lower net cost. See infra note 228. 


\section{Differing Calculations of the Amount At Risk Under Section 465 and Under the Investment Tax Credit Section.}

Once one determines the parameters of an "activity" under section 465 , the amount-at-risk in that activity acts as a ceiling upon the amount of loss a taxpayer can spill over from that activity to shelter income derived from other, unrelated activities. The following considerations determine the taxpayer's aunount-at-risk (AAR) in an activity under section 465 . The taxpayer becoines at-risk with respect to any amount of money or property that he contributes to the section 465 activity. 177 If the taxpayer contributes property he becomes at-risk with respect to an anount equal to the contributed property's adjusted basis rather than its fair market value. ${ }^{178}$ In general, amounts borrowed and contributed to any activity by a taxpayer qualify as amounts-at-risk if he remains personally liable for repayment or if he has pledged unrelated property not used in the activity as security for the borrowed anounts. ${ }^{179}$ In this situation the taxpayer becomes at-risk with respect to an amount equal to his personal liability or the net fair inarket value of the pledged property. ${ }^{180}$

Section 46(c)(8) incorporates section 465 criteria to determine the amount of at-risk investunent in section 38 property. Thus, if a taxpayer purchases five-year property, entitling him to an investment credit of $10 \%$ of his qualified investment, and if he pays $\$ 40,000$ for the property in the forin of $\$ 10,000$ cash and a nonrecourse note of $\$ 30,000$, he has $\$ 10,000$ at risk in the property. He can therefore receive a $\$ 1,000$ credit ( $10 \%$ of the $\$ 10,000$ cash investment). Personal liability on the $\$ 30,000$ obhgation would imcrease his AAR in the property to $\$ 40,000$, entitling him to a $\$ 4,000$ credit.

When the taxpayer engages in any of the five suspect enuinerated activities remaining im section $465,{ }^{181}$ however, the Code imposes a much stricter rule. ${ }^{182}$ In these five activities, borrowed money does not constitute an AAR if the taxpayer borrows it from a person with an "interest" 183 in the activity other than as a creditor, or from a person

177. See I.R.C. $\S 465(b)(1)(A)(1976)$.

178. See id.

179. I.R.C. $\S 465(b)(2)$ (1976).

180. See id.

181. See I.R.C. $\S 465$ (c)(1) (1976 \& Supp. IV 1980); supra notes $139-41$ and accompanying text.

182. See 1.R.C. $\S 465(b)(3)$, (c)(3)(E) (1976 \& Supp. IV 1980).

183. 1.R.C. $\S 465(b)(3)$ (1976 \& Supp. IV 1980); Proposed Treas. Reg. $\S 1.465-8$, Fed. TAXES (P-H) ๆ 20,648.38 (1982). 
who is "related" to the taxpayer. ${ }^{184}$ A literal reading of section 46(c)(8) now applies these strict rules to the determination of credit for investment in ehgible property used in any of the five activities even when the activity generates no section 465 (d) loss. Obviously, the determination of the AAR involves some complex considerations. Some even more esoteric factors can apply, including (1) the effects of disqualified loans on property other than that used in the five enuinerated activities, (2) special IRS contingency factors affecting the AAR, (3) the effects on the AAR of a recourse note becoming nonrecourse, (4) the availability of safe harbors for certain financing, and (5) the effects of a fiuctuating AAR on credit or recapture.

1. Effect of Disqualified Loans on the Investment Credit. Under the two-stage structure of section 465, a zero AAR has no independent adverse effect on the taxpayer's activity producing the zero risk. A nonrecourse loan, for exainple, poses a tax problein only when the activities consuming the loan generate excess deductions and the taxpayer attempts to transfer those excess deductions to shelter unrelated income. At that second stage, the absence of an AAR limits the taxpayer's ability to offset income with those excess deductions.

In contrast, under the one-dimensional approach of section 46(c)(8), "the basis of such property . . . shall not exceed the amount the taxpayer is at-risk with respect to such property as of the close of such taxable year."185 Consequently, the strict section 465 rules disqualify certain loans obtained to acquire eligible property, result in zero at-risk investment in property used in the covered activities, and prevent an apparently valid credit. If, for example, a farmer borrowed $\$ 10,000$ froin a "related" person such as his sister, and used the funds to purchase needed farm machinery, the loan would be disqualified. It would produce zero AAR in, and zero investment credit for, the otherwise ehgible section 38 equipment. The farmer could lose the entire investment credit because of the nature of the financing for the prop-

184. See infra notes 207-11 and accompanying text. Congress also authorized the Secretary of the Treasury to extend this strict rule to other, non-statutory, activities by regulation. See l.R.C. $\S 465$ (b)(3)(B) (1976 \& Supp. IV 1980). The rule, on its face, appears to apply to all section 465 activities. The strict rule of section $465(b)(3)$ actually applies to the non-enumerated activities, i.e., those described in subparagraph (A) of section $465(\mathrm{c})(3)$ and those added to the section 465 coverage in the 1978 comprehensive extension of the section, only to the extent the Secretary so provides by regulation. See I.R.C. $\$ 465$ (c)(3)(E) (Supp. IV 1980). This interpretation of the Code follows from the general rules of construction in the proposed regulations: "For the purposes of the regulations under section 465 , unless expressly provided otherwise, use of the term 'activity' shall refer to an activity whieh is described in section 465(c)(1)." Proposed Treas. Reg. § 1.4659(c), FED. TAXES (P-H) \20,648.39(c) (1982).

185. I.R.C. $\$ 46(c)(8)$ (West Supp. 1982). 
erty, even though in that same year he had no section 465(d) loss and his farm in fact produced sizeable taxable income.

2. Other Factors Affecting the AAR. The Treasury has developed other criteria in the tax abuse context of section 465 which may foreclose recognition of AAR for a taxpayer even though he appears subject to personal hability in his activity. Busimess enterprises now subject to the at-risk restrictions of section $46(\mathrm{c})(8)$ will find their investment credit jeopardized if the financial arrangements for acquiring the property possess any of these additional proscribed characteristics.

Section 465 , for example, demes at-risk status to any amount "protected against loss through nonrecourse financing, guarantees, stop loss agreements, or other similar arrangements." 186 Because this restriction applies to all activities covered by section 465 , rather than only to the five enumerated suspect activities, it has a broad impact on a taxpayer's mvestment tax credit. Although the taxpayer acquires property by contributing his own money or by borrowing funds from disinterested and unrelated lenders on obligations for which he is personally liable, these contributions will not generate an AAR if the IRS deems the taxpayer protected against loss. ${ }^{187}$ As a corollary, collateralized nonrecourse loans do not generate an AAR if the taxpayer is protected against loss of the collateral. ${ }^{188}$

The regulations extend this theory into surprising territories, and, because of the ERTA, now affect the availability of the investment credit. Thus, if a taxpayer must repay a loan only if a certain contingency occurs, whether such loan will give rise to an AAR depends upon "the likelihood of the contingency occurring." 189 If the Treasury considers the occurrence of the contingency "unlikely," then it deems the taxpayer protected against loss and investment of the borrowed funds produces no AAR. ${ }^{190}$

Thus, the Treasury and the taxpayer embark on an uncertain journey of predicting probabilities. Contingencies may be far beyond the control of the taxpayer, but the Treasury's interpretation will prevail. Our farmer, for example, may borrow $\$ 10,000$ froin a disinterested unrelated lender, pledge his future crops as security for the loan, and agree to assume personal liability only if flooding destroys those crops.

186. I.R.C. $\$ 465(b)$ (4) (1976 \& Supp. IV 1980).

187. See Proposed Treas. Reg. $\S$ 1.465-6(a), FED. TAXES (P-H) $\llbracket 20,648.36$ (a) (1982).

188. Id.

189. Proposed Treas. Reg. § 1.465-6(c), FeD. TAXEs (P-H) ๆ 20,648.36(c) (I982).

190. Id. The taxpayer has an AAR "if the likelihood of the contingency occurring is such that the taxpayer is not effectively protected against loss, . . or if the protection against loss does not cover all likely possibilities." Id. 
The farmer may have become contingently liable for nothing because, as the regulation states, the Treasury has determined that this loan arrangement effectively protects him against loss:

While drought is a constant concern for farmers in the area, flooding is not. Accordingly, although ... [the farmer] is personally liable in the event of flooding, ... . [his] amount at risk will not be increased unless flooding actually occurs and destroys the crops, because the likelihood of flooding is such that ... [the farmer] is effcctively protected against loss. ${ }^{191}$

Recognizing the possibility that it may not possess infallible judgment about the weather, the Treasury graciously allows the farmer to consider the $\$ 10,000$ loan proceeds as producing an AAR at the end of any year in which flooding does occur. ${ }^{192}$

Under section 465 , this Treasury position allows the farmer to deduct all expenses up to the amount equal to his farm income in dry years, even though he has no AAR. In the year of the flood, he can then take excess deductions froin his farming activity, up to the $\$ 10,000$ loan amount, as deductions to shelter income from other activities. But, under section 46(c)(8)'s structure of the investment credit, the farmer may never derive any tax benefit whatsoever froin the purchase of section 38 property with these funds. In later years, if the loan does generate an AAR because a flood occurs and the farmer is no longer deemed protected against loss, it is unclear whether the farmer will then receive any investinent credit benefit under section 46(c)(8). ${ }^{193}$

3. Effect on the AAR of a Recourse Note That Becomes Nonrecourse. In the converse of our farmer's nonrecourse note that might become recourse if a flood occurs, the Service has developed the position under section 465 that if an obviously recourse obligation becomes nonrecourse upon the occurrence of an event or a lapse of time, the Service may examine all of the facts and circumstances to determine if the recourse note is sufficiently genuine to generate any at-risk investment. Specifically, the funds borrowed on such an obligation will produce an AAR only if the reasons for entering into the arrangement "are primarily business inotivated and not primarily related to Federal income tax consequences," and the "borrowing arrangement is consistent

191. Proposed Treas. Reg. $\$ 1.465-6($ e)(Ex. 3), Fed. TAXEs (P-H) \ 20,648.36(e) (1982). Although the examples of the Treasury's proposed regulations only refer to situations where the taxpayer engages in one of the five suspect activities enumerated in section 465 (c)(1), the statutory authorization of section 465 (b)(4) to deny an AAR to those taxpayers who protect themselves from loss is not limited to the five tainted activities. Presumably, therefore, these concepts apply to all covered taxpayers and all covered activities.

192. See Proposed Treas. Reg. $\$ 1.465-6(e)(E x .3)$, Fed. TAXEs (P-H) $\| 20,648.36(e)(E x .3)$ (1982).

193. See infra text accompanying notes $217-22$. 
with the normal commercial practice of financing the activity for which the money is being borrowed." 194

A recent Revenue Ruling 195 illustrates the type of scrutiny with which the IRS views such obligations. A taxpayer had purchased equipment having a seven-year useful life for a price of $\$ 275,000$ consisting of $\$ 25,000$ cash and a note in the amount of $\$ 250,000$ for the balance of the purchase price. The note did not require any payment of principal before the end of its seven-year term. During that sevenyear terin the taxpayer remained personally liable on the note. At the end of that period, by paying an additional $\$ 10,000$, the taxpayer could convert the note imto a nonrecourse obhigation. The IRS observed that the conversion occurred at a time when the equipment had been fully depreciated, was "likely to have significantly declined in value,"196 and occurred whether the value of the property remamed sufficient to assure payment of the note. The Commissioner found, therefore, that the reason for requiring the imvestor to personally assume liability during the initial seven-year period was the tax-motivated desire to increase the at-risk investment, and not to secure repayment of the note. ${ }^{197}$ "Because the ... financing arrangeinent [was] entered into primarily to avoid the limitations of section $465 \ldots$ and not primarily for business reasons," 198 the Ruling deternined that the $\$ 240,000$ net amount of the note (the $\$ 250,000$ face value minus the $\$ 10,000$ cash payment due for the privilege of conversion to a nonrecourse note) was equivalent to a nonrecourse note and generated no AAR even during the seven-year period when the taxpayer was, on the face of the note, personally hable. ${ }^{199}$

194. See Proposed Treas. Reg. \& 1.465-5, Fed. Taxes (P-H) ๆ 20,648.35 (1982); see also Rev. Rul. 413, 1978-2 C.B. 167.

195. Rev. Rul. 283, 1981-2 C.B. 115.

196. Id. at 116.

197. $I d$.

198. Id.

199. The Service distinguished this result from the convertible recourse notes examined in the legislative history of section 465 as genuine notes that generated an at-risk investment. Id. The Service asserted that in the latter examples, the event that triggered the conversion of a note from recourse to nonrecourse had "a substantial economic relationship to the activity": conversion occurred when the property had grown sufficiently in value to serve as security for repayment of the debt so that the lender no longer needed the personal liability of the taxpayer on the obligation to assure his collection of the note. See S. REP. No. 938, 94th Cong., 2d Sess. 48 n.1 (1976), reprinted in 1976-3 C.B. 57, 86 n.l. The Senate Finance Committee used as an illustration a note that converted from recourse to nonrecourse when an orchard reached a certain stage of development. See id. In addition, the House Ways and Means Committee recognized that a recourse loan would be genuine and create an AAR even though it became nonrecourse when a specified event occurred-in the case of a note obtained to acquire a movie, at the time when a movie "reaches a certain stage of completion or generates a certain level of box office receipts." $H$. R. REP. No. 658, 94th Cong., Ist Sess. 110 n.10 (1975), reprinted in 1976-3 C.B. 701, 802 n.10. 
The Service's position on convertible recourse notes is clearly directed at tax abuses. Under section 465 this position would have no initial adverse tax consequence to a businessman or investor who was not trying to spill over excess deductions from one activity in order to shelter unrelated income derived from another activity. In contrast, the IRS position reaches further in the investinent credit area because it applies at the outset to deny the taxpayer an at-risk investment in otherwise eligible property. The taxpayer will lose the entire credit at the outset if the Service determines that the arrangement has no substantial economic basis. At best, this creates a new source of dispute with the government as to the taxpayer's motive for his financing arrangement, and adds another element of uncertamty with respect to the availability of the investinent credit.

4. The Investment Credit Safe Harbor for "Certain Financing." A "qualified investinent" now generally depends on the taxpayer's personal liability when acquiring eligible section 38 property. Some of the problems with determining this liability have been discussed above. The ERTA did, however, add a safe harbor for certain borrowed amounts that otherwise generate no personal liability. ${ }^{200}$ Section 46(c)(8) now generally allows a purchaser of section 38 property to claim an AAR equal to $100 \%$ of the borrowed amount if (1) he is at-risk for an amount equal to at least $20 \%$ of the basis of the eligible property; ${ }^{201}$ (2) he acquires the property froin a person other than a "related person;" and (3) he borrows only from a "qualified person" or any federal, state or local governinent. ${ }^{202}$

Congress apparently designed these safe harbor provisions to mobilize private financial institutions in the attack on tax shelter schemes. If an unrelated financial institution will lend as inuch as $80 \%$ of the acquisition cost of eligible section 38 property, relying solely on the security of the property, then presumably the loan transaction constitutes prima facie evidence that the reported value of the property is reasonable. The Service, in turn, inust assuine that the taxpayer has not overvalued the property to obtain an inflated depreciation and investment credit basis. The use of the private sector in this way is sound, but the statutory requirements are cumbersome and create pitfalls for the unwary purchaser of section 38 property.

One pitfall looms in the meaning of the terin "related person."203

200. ERTA $\S 211$ (codified at I.R.C. $\$ 46(c)(8)(B)$ (ii) (West Supp. 1982)).

201. Section $46(c)(8)(B)(i i)$ requires that the basis of eligible property be computed under the rules of I.R.C. $\S 168(d)(1)(A)$ (i) (West Supp. 1982).

202. I.R.C. $\S 46(\mathrm{c})(8)(B)(i i)$ (West Supp. 1982).

203. The crucial definition of a "related person" reads as follows: 
The benefits of the safe harbor do not accrue to a taxpayer who acquires the property from a related seller. ${ }^{204}$ Certam family members are clearly related. ${ }^{205}$ In addition, the safe harbor is not available if the taxpayer acquires section 38 property from a corporation or partnership in which he or the lender directly or indirectly owns more than $10 \%$ of the value of all equity imterests. ${ }^{206}$ Reciprocally, if the seller of the property owns more than $10 \%$ of the value of all equity interests in the taxpayer or the lender, he is a related person, and the taxpayer cannot use the safe harbor. ${ }^{207}$

Even tighter rules govern the qualification of lenders under the safe harbor. Related family members are clearly disqualified. ${ }^{208}$ To qualify, traditional mstitutions such as banks, savings and loan associations, credit unions, imsurance companies, certain pension trusts, and others actually and regularly engaged in the business of lending inoney may not be related to the taxpayer, and may not be the seller or related to the seller. ${ }^{209}$ Thus, the lender of a nonrecourse loan does not qualify under the safe harbor a taxpayer seeks if the taxpayer or the seller directly or indirectly owns more than $10 \%$ of the value of all the lender's equity interests. ${ }^{210}$ Nor will the lender qualify if it owns more than $10 \%$ of the value of all equity interests $i m$ the taxpayer or the seller. ${ }^{211}$ Nonrecourse loans from pension trusts and commercial lenders face further barriers: any overlapping ownership of equity interest between the lender, the taxpayer, and the seller or person related thereto, will prevent the nonrecourse loan from qualifying under the safe harbor. ${ }^{212}$

\footnotetext{
For purposes of this paragraph, the term "related person" has the same meaning as such term is used in section 168(e)(4), except that in applying section 168(e)(4)(D)(i) in the case of a person described in subparagraph (D)(i)(II) of this paragraph, sections 267(b) and 707(b)(1) shall be applied by substituting "zero percent" for "50 percent."

I.R.C. $\$ 46(c)(8)(E)$ (West Supp. 1982). I.R.C. section 168(e)(4) (West Supp. 1982), one of the four Code sections cross-referenced in the definition of a "related person," cross-references I.R.C. section 52 which, in turn, cross-references and modifies I.R.C. section 1563. Such drafting of a key definition in a safe harbor provision makes a mockery of Congress' avowed aim to simplify the new rules on the investment credit.

204. See I.R.C. $\S 46(c)(8)$ (B)(ii) (West Supp. 1982).

205. Tainted family members include the taxpayer's spouse, ancestors, lineal descendants, and brothers and sisters (whether by the whole or half blood). See I.R.C. § 267(b), (c)(4) (1976).

206. See I.R.C. $\$ 168(e)(4)(D)$ (West Supp. 1982). The test of "more than 10\%" is applied at the time the taxpayer acquires the section 38 property. See Joint CommitTeE Explanation of ERTA, supra note 38, at 109.

207. For an explanation of a "related person" under section 168(e)(4)(D), see JoINT CommirTEE EXPLANATION OF ERTA, supra note 38, at 109.

208. I.R.C. $\S 46$ (c)(8)(B)(ii)(I), (D)(ii) (West Supp. 1982).

209. See I.R.C. $\S \S 46(\mathrm{c})(8)(\mathrm{E}), 168(\mathrm{e})(4), 52(\mathrm{a}),(\mathrm{b}), 1563$ (West Supp. 1982).

210. See I.R.C. $\$ \S 46(\mathrm{c})(8)(E), 168(\mathrm{e})(4)(D)$ (West Supp. 1982); Jornt Committee ExplanaTION OF ERTA, supra note 38 , at 109.

211. See Joint Commirtee Explanation of ERTA, supra note 38, at 97.

212. This conclusion follows from the modification made by enactment of I.R.C. section
} 
Latent dangers exist even for a loan that appears to meet the safe harbor requirements. ${ }^{213}$ Suppose a taxpayer purchases property from someone not related to him, has an at-risk mvestment of $20 \%$ of the basis of the property, and borrows the other $80 \%$ from a qualified lender not related to him or the seller. The ERTA's legislative history reveals that the IRS may recharacterize such transactions, origmally cast im the form of a financing arrangement between the taxpayer and a lender, as a sale or lease. This recharacterization would make the lender also the person from whom property was acquired, and thus disqualify him as a lender. The taxpayer would then lose the benefit of the safe harbor, 214 and the nonrecourse loan would generate no AAR and zero qualified imvestment for the imvestment credit.

The safe harbor restrictions that mandate a qualified lender, however, only apply during the first twelve months of a loan. ${ }^{215}$ Once this period elapses, arrangements may be made to transfer the loan to a nonqualified person without adversely affecting the taxpayer's AAR. Thus, with one inajor caveat, after twelve inonths a person related to the taxpayer or the seller could assuine safe harbor $80 \%$ nonrecourse loans previously held by, say, an independent bank. Because during the first twelve inonths the existence of an agreement to transfer the loan to an unqualified person is fatal, and because the statute does not require the agreement to be in writing, any transfer shortly after the twelve-inonth period would justify an inquiry by the IRS to determme whether an unwritten agreement or understanding to inake the transfer had existed. Such an agreeinent would retroactively disqualify the loan. For example, if a seller usually finances sales of its equipment through a qualified imdependent bank, but also regularly arranges for the transfer of the financing in month thirteen of every loan to an organization related to the seller, the IRS will undoubtedly contend that such a pattern evidences a pre-existing agreement that disquahifies the entire transaction from safe harbor treatment.

As the statute now stands, sophisticated promoters of tax shelter opportunities with constant access to skilled tax counsel can profitably take advantage of the safe harbor. The small busmessman or closely

\footnotetext{
46(c)(8)(E) (West Supp. 1982), which reduced to zero the 10\% control test of I.R.C. section 168(e)(4)(D)(i) (West Supp. 1982).

213. See Joint Committee Explanation of ERTA, supra note 38, at 97; I.R.C. $\S 46(c)(8)(D)(i)(I I)$, (iv) (West Supp. 1982).

214. See Joint Committee Explanation of ERTA, supra note 38, at 97; I.R.C. $\S 46(c)(8)(D)(i)(I)$, (iv) (West Supp. 1982).

215. I.R.C. § 47(d)(2) (West Supp. 1982).
} 
held business, however, with no pervasive tax avoidance inotive and no experience in tax shelter concepts, will probably not attempt to use the safe harbor. ${ }^{216}$ Even knowledgeable businessmen inay be reluctant to spend the money and time necessary to understand and comply with the technical requirements of the statute, and then search out the data on the underlying equity ownership of the equipment seller, the financing institution, and possibly related persons for each item of section 38 property purchased and financed. Such costs could easily outweigh the tax savings that would otherwise be gained from the investment credit. In the last analysis, the safe harbor inay primarily serve as an accommodation for the putative tax shelterer.

5. Fluctuating AAR Causes Additional Investment Credit or Recapture. Under section 465, a complex set of regulations governs increases and decreases in a taxpayer's AAR in an activity. ${ }^{217}$ In lieu of extending the scope of these regulations, Congress adopted new sections to control increases in the taxpayer's AAR under the investment credit $^{218}$ and to control recapture of the credit when the taxpayer's

216. It is appropriate to compare the safe harbor of section $46(c)(8)$ and the safe harbor of the leveraged lease arrangements in section $168(f)(8)(B)(i i)$. A publicly held company remains exempt from the general at-risk provisions of the investment credit under section $46(c)(8)$ and can obtain the full credit notwithstanding its use of nonrecourse financing, its zero AAR, and its active use of investment credits from one activity to shelter income derived from an unrelated activity. See supra notes 129-35 and accompanying text. If, however, such corporations wish to transfer their investment credits from a loss company to a profitable company under a leveraged lease arrangement, Congress requires the lessor to have a minimum investment of $10 \%$ in the adjusted basis of the property. The $10 \%$ equity investment includes consideration paid or recourse debt incurred by the lessor in acquiring the property. The limitation also requires that the lessor not obtain the $10^{\circ} \mathrm{C}$ investment from the lessee or a person related to the lessee. No restrictions apply to the funds representing the remaining $90 \%$ of the cost of the property. The funds, therefore, may consist of nonrecourse financing or of funds wholly borrowed from related persons. Because the leveraged lease rules do not incorporate section 465 restrictions, public companies that transfer credits are not enmeshed in the web of section 465 regulations. Moreover, the leveraged lease sections deviate expressly from the approach of section $465(\mathrm{~b})(4)$ : the amount that the lessor has at risk in the property will not be affected by the existence of an agreement that may protect the lessor or the lessee against loss by requiring a purchase or sale of the equipment at a fixed price at the end of the lease term. I.R.C. $\S 168(f)(8)(E)$ (repealed 1976).

The TEFRA eliminated some of these discrepancies. The safe harbor leasing rules are not available for leases entered into by certain related parties. See TEFRA § 208(b). The TEFRA does, however, operate to exclude closely held corporate lessors-other than personal service companies-from the section 465 rules if the safe harbor leasing activity involves certain types of depreciable property and if the lease is entered into or the property placed in service after July 1 , 1982. In this situation, the closely held lessor will be considered at-risk in an amount equal to the amount that the lessee-as true owner-would have been considered at-risk if true economic substance controlled the classification of all the parties. See id.

217. See Proposed Treas. Reg. $\S \S 1.465-20$ to $-26,-38,-39,-41$, Fed. TAXes (P-H) I 53,365 (1982).

218. See 1.R.C. $\$ 46(c)(9)$ (West Supp. 1982). 
AAR decreases. ${ }^{219}$ Under these new provisions, the taxpayer's AAR in a particular property increases only when he increases his actual investinent in the property. Repayment of nonrecourse debt incurred to acquire section 38 property increases the taxpayer's AAR in that item; repayment of recourse debt does not.220 Under the new sections, unlike sections 465,221 reinvested operating profits do not increase the AAR for investment credit purposes unless the taxpayer can trace those profits to investments in eligible section 38 property or to repayment of nonrecourse debt incurred by investment in section 38 property. If the taxpayer does increase his AAR in any property, he recomputes his investment credit as if he had been personally liable for the increased amount when the property was originally placed in service. ${ }^{222}$ A resulting increase in credit decreases the tax due in the year of the actual mvestment increase.

Similarly, a taxpayer's AAR im section 38 property decreases if his investment in the property decreases. Under the new provisions, in contrast to section 465 , neither distributions of inoney from a business or investment activity nor ACRS or depreciation deductions reduce the taxpayer's AAR in a particular piece of eligible property. ${ }^{223}$ The section 46(c)(8) property-by-property analysis does, however, decrease the AAR when a taxpayer converts recourse debt on a piece of property into a form of nonrecourse debt or debt for which the Code treats the taxpayer as not at-risk. 224

Decreases in the AAR can change recapture, just as increases can change the amount of credit. Prior to the enactment of the ERTA, a recapture of investment credit depended solely on the time factor. ${ }^{225}$ If the origimal taxpayer held the property for the required period, he was not subject to recapture. Congress, however, added a new dimension of complexity: changes in the nature of the financing prior to the expiration of the appropriate holding period can trigger premature recapture. ${ }^{226}$ If the taxpayer reduces his at-risk investment in any property, the credit originally allowed for acquisition of that property must be

219. See I.R.C. § 47(d) (West Supp. 1982).

220. See Jolnt Committee Explanation of ERTA, supra note 38, at 99.

221. See Proposed Treas. Reg. § 1.465-22(c), FED. TAXES (P-H) \% 20,648.52 (1979) (allowing reinvested operating profits derived from a business activity to increase AAR in that activity).

222. See Joint Commitree Explanation of ERTA, supra note 38, at 99.

223. See id. at 99-100. If the financing fulfills the requirements of the safe harbor of section 47(d)(2), the transfer of a loan from a qualified lender to a non-qualified lender, after the 12month grace period, will not reduce the taxpayer's AAR. See I.R.C. \& 47(d)(2) (West Supp. 1982).

224. See Joint Committee Explanation of ERTA, supra note 38, at 99-100.

225. See I.R.C. $\$ 47$ (West 1967 \& Supp. 1982).

226. See ERTA $\S 211($ (f)(2), 231-33 (codified at I.R.C. $\S 47$ (d) (West Supp. 1982)). 
redetermined as if the taxpayer had invested only the reduced AAR when he originally placed the property in service. Any excess credit previously allowed increases his tax liability in the year in which the AAR decreases. 227

\section{CONCLUSION}

By enacting the ERTA and the TEFRA, Congress not only made the investment tax credit more lucrative, but also introduced at-risk rules designed to protect the credit from inisuse by zealous tax slielterers. The at-risk rules, however, constitute a case of overkill. The language of section $46(c)(8)$ often denies the investment credit to profitable, active small businesses that engage in no tax sheltering activities and no abusive practices. The Code simply presumes them guilty of abuse when they purchase property, normally eligible for the investment credit, with a form of financing that involves no personal liability. The at-risk provisions mete out the same tax punishment for nonrecourse financing-a denial of the investment credit-to the tax shelterer and to the legitimate small business alike.

Although the at-risk concepts of section 465 and section 46(c)(8) both aim to himit otherwise allowable tax preferences to the amount of the taxpayer's genuine economic investment, the effect of section 46(c)(8) is much more draconian. Because the code measures the atrisk amount in the investment credit field on a property-by-property approach, the new at-risk rules of section 46(c)(8) completely deny an investment tax credit to taxpayers who, under section 465 , would feel no adverse consequences until their otherwise allowable deductions exceeded the amount of incoine derived from their activity. Section 465 only limits a taxpayer's use of losses from one activity to reduce tax on incoine froin an unrelated activity; it does not represent an absolute statutory condemnation of nonrecourse indebtedness, which often serves legitimate commercial purposes existing independent of tax considerations. ${ }^{228}$ In section $46(\mathrm{c})(8)$, the section 465 rules are extended

227. See I.R.C. $\S 47(d)(1)$ (West Supp. 1982).

228. For an illustration of one legitimate, independently motivated use of nonrecourse financing, see supra note 176. Another important use of nonrecourse financing involves sole proprietors and closely held corporations seeking to expand their capital base. Principal lenders often draft sophisticated loan agreements that limit the borrowing power of these businesses. These loan agreements often permit the use of nonrecourse financing, which does not affect personal liability. Thus, nonrecourse borrowing may represent the only financing alternative open to these businesses desiring to acquire new machinery and equipment normally eligible for the investment credit. In these instances, the use of the at-risk provisions as the sole criterion for tax shelter activity again operates to disadvantage privately held companies in competing with their publicly held counterparts. 
beyond their spirit when they are used to create an unfair and often inaccurate presumption of tax shelter activity for every item of tangible depreciable property acquired with a nonrecourse loan. If the investment credit is to survive as an effective tax expenditure, Congress must avoid burdening the subsidy with overbroad anti-tax-shelter machinery.

Congress could alter this harsh approach by according the same treatment to imvestment credits under section $46(\mathrm{c})(8)$ as to deductions under section 465. This would involve incorporating into section 46(c)(8) the two-stage activity structure of section 465 so that the investment credit would be fully available to a taxpayer deriving income from only one activity, trade or business. At-risk restrictions would operate only if the taxpayer attempted to use the investment credit generated from an originating activity as a device to shelter tax on income derived from a second unrelated or unaggregated activity.

Congress might even go further and reevaluate the broad coverage of both sections 465 and 46(c)(8) with an eye toward eliminating the present discrimination against small businesses in favor of large, widely held corporations. ${ }^{229}$ Small taxpayers must face the complex at-risk restrictions and burdens of compliance described in this article even when involved in active businesses with no tax avoidance conduct, yet large corporations remain immune from admmistrative and judicial scrutiny under the at-risk rules even if they invest in aggressive and questionable tax shelters. A more reasoned approach suggests that the Code use objective criteria that more accurately focus on the legitimacy of a business enterprise. A considered expansion of the active participation concept of section 465(c)(3)(B), for example, could ensure the existence of a legitimate business venture. In this way the Code could distinguish between the tax shelterer who deserves to face the rigorous new at-risk tests and the actively managed enterprise carrying on a bona fide trade or business that deserves to be free of the at-risk exposure even if it does happen to be small and closely held.

229. In light of other statutory and administrative anti-tax-shelter weapons, see supra note 123, the need for the current discrimination against privately held businesses appears, at best, to deserve further review and discussion.

In the context of safe harbor leasing transactions, the TEFRA exempts certain closely held corporations from the at-risk provisions of the Code. See supra note 216. This exclusion is worthy of support and expansion, but is unfortunately scheduled to terminate with the expiration of the safe harbor lease provisions on December 31, 1983. 